\title{
European first-year university students accept evolution but lack substantial knowledge about it: a standardized European cross-country assessment
}

Paul Kuschmierz ${ }^{*}$ (D), Anna Beniermann², Alexander Bergmann ${ }^{3}$, Rianne Pinxten ${ }^{4}$, Tuomas Aivelo $^{5}$, Justyna Berniak-Woźny ${ }^{6}$, Gustav Bohlin, Anxela Bugallo-Rodriguez ${ }^{8}$, Pedro Cardia”, Bento Filipe Barreiras Pinto Cavadas ${ }^{10}$, Umran Betul Cebesoy ${ }^{11}$, Dragana D. Cvetković ${ }^{12}$, Emilie Demarsy ${ }^{13}$, Mirko S. Đorđević ${ }^{14}$, Szymon M. Drobniak ${ }^{15}$, Liudmyla Dubchak ${ }^{16}$, Radka M. Dvořáková ${ }^{17}$, Jana Fančovičová ${ }^{18}$, Corinne Fortin ${ }^{19}$, Momir Futo ${ }^{20}$, Nicoleta Adriana Geamănă ${ }^{21}$, Niklas Gericke ${ }^{22}$, Donato A. Grasso ${ }^{23}$, Konstantinos Korfiatis ${ }^{50}$, Ádám Z. Lendvai ${ }^{24}$, Evangelia Mavrikaki ${ }^{25}$, Andra Meneganzin ${ }^{26}$, Athanasios Mogias ${ }^{27}$, Andrea Möller ${ }^{28}$, Paulo G. Mota ${ }^{29}$, Yamama Naciri30 , Zoltán Németh ${ }^{24}$, Katarzyna Ożańska-Ponikwia ${ }^{31}$, Silvia Paolucci ${ }^{32}$, Péter László Pap ${ }^{33}$, Maria Petersson ${ }^{34}$, Barbara Pietrzak ${ }^{35}$, Telmo Pievani ${ }^{26}$, Alma Pobric ${ }^{36}$, Juris Porozovs ${ }^{37}$, Giulia Realdon ${ }^{38}$, Xana Sá-Pinto ${ }^{39}$, Uroš B. Savković ${ }^{14}$, Mathieu Sicard ${ }^{40}$, Mircea T. Sofonea ${ }^{41}$, Andrej Sorgo ${ }^{42}$, Alexandru N. Stermin ${ }^{43}$, loan Tăușan ${ }^{44}$, Gregor Torkar ${ }^{45}$, Lütfullah Türkmen ${ }^{11}$, Slavica Tutnjević ${ }^{46}$, Anna E. Uitto ${ }^{47}$, Máté Varga ${ }^{48}$, Mirna Varga ${ }^{49}$, Lucia Vazquez-Ben ${ }^{8}$, Enrique Viguera ${ }^{51}$, Lisa Christine Virtbauer ${ }^{52}$, Albena Vutsova ${ }^{53}$, Inmaculada Yruela ${ }^{54}$, Jelle Zandveld ${ }^{55}$ and Dittmar Graf ${ }^{1}$

\begin{abstract}
Background: Investigations of evolution knowledge and acceptance and their relation are central to evolution education research. Ambiguous results in this field of study demonstrate a variety of measuring issues, for instance differently theorized constructs, or a lack of standardized methods, especially for cross-country comparisons. In particular, meaningful comparisons across European countries, with their varying cultural backgrounds and education systems, are rare, often include only few countries, and lack standardization. To address these deficits, we conducted a standardized European survey, on 9200 first-year university students in 26 European countries utilizing a validated, comprehensive questionnaire, the "Evolution Education Questionnaire", to assess evolution acceptance and knowledge, as well as influencing factors on evolution acceptance.
\end{abstract}

*Correspondence: Paul.Kuschmierz@didaktik.bio.uni-giessen.de

${ }^{1}$ Institute for Didactics of Biology, Justus-Liebig-University Giessen, Giessen,

Germany

Full list of author information is available at the end of the article

(c) The Author(s) 2021, corrected publication 2022. Open Access This article is licensed under a Creative Commons Attribution 4.0 International License, which permits use, sharing, adaptation, distribution and reproduction in any medium or format, as long as you give appropriate credit to the original author(s) and the source, provide a link to the Creative Commons licence, and indicate if changes were made. The images or other third party material in this article are included in the article's Creative Commons licence, unless indicated otherwise in a credit line to the material. If material is not included in the article's Creative Commons licence and your intended use is not permitted by statutory regulation or exceeds the permitted use, you will need to obtain permission directly from the copyright holder. To view a copy of this licence, visit http://creativecommons.org/licenses/by/4.0/. The Creative Commons Public Domain Dedication waiver (http://creativecommons.org/publicdomain/zero/1.0/) applies to the data made available in this article, unless otherwise stated in a credit line to the data. 
Results: We found that, despite European countries' different cultural backgrounds and education systems, European first-year university students generally accept evolution. At the same time, they lack substantial knowledge about it, even if they are enrolled in a biology-related study program. Additionally, we developed a multilevel-model that determines religious faith as the main influencing factor in accepting evolution. According to our model, knowledge about evolution and interest in biological topics also increase acceptance of evolution, but to a much lesser extent than religious faith. The effect of age and sex, as well as the country's affiliation, students' denomination, and whether or not a student is enrolled in a biology-related university program, is negligible.

Conclusions: Our findings indicate that, despite all their differences, most of the European education systems for upper secondary education lead to acceptance of evolution at least in university students. It appears that, at least in this sample, the differences in knowledge between countries reflect neither the extent to which school curricula cover evolutionary biology nor the percentage of biology-related students in the country samples. Future studies should investigate the role of different European school curricula, identify particularly problematic or underrepresented evolutionary concepts in biology education, and analyze the role of religious faith when teaching evolution.

Keywords: Evolution, Acceptance, Knowledge, Multilevel modeling, Socioscientific issues, Religious faith, Higher education, Europe, Assessment, Attitude

\section{Introduction}

Most experts in the fields of biology (e.g., Dobzhansky 1973) and science education (e.g., Harms and Reiss 2019) agree that evolution is crucial to understanding biology. For this reason, the assessment of acceptance and understanding of evolution is a central topic in science education research (Dunk et al. 2019). Over the last few decades, researchers from various disciplines have investigated knowledge and acceptance of evolution and their mutual relationship between different age groups and education levels (e.g., Clément 2015; Dunk et al. 2017; Fiedler et al. 2019; Ha et al. 2019; Mead et al. 2018; Romine et al. 2017; Sbeglia and Nehm 2018), as well as in the general public (Brenan 2019; European Commission 2005; Hameed 2008; Ipsos Global @dvisory 2011; Pew Research Center 2015).

The discussion of the relationship between acceptance and understanding of evolution is still ongoing because of diverging findings (Barnes et al. 2019; Dunk et al. 2019). For instance, several studies discovered a positive relationship between knowledge about evolution and acceptance of evolution (e.g., Athanasiou et al. 2012; Ha et al. 2015; Rutledge and Warden 2000), while others described only weak or even negligible relationships (e.g., Barnes et al. 2017b; Graf and Soran 2010; Torkar and Šorgo 2020). An overview of different empirical findings is available in Fiedler et al. (2019). Some studies that compared different target groups showed that the strength of the relationship is increasing with the level of education (Beniermann 2019; Kuschmierz et al. 2020b).

Although more than 300 articles on acceptance of evolution have been published to date, little consensus has emerged on the primary factors that contribute to this construct (Barnes et al. 2019). However, some studies found religiosity (Beniermann 2019; Barnes et al. 2019), understanding the nature of science (Graf and Soran 2010; Dunk et al. 2017), or attitudes towards science (Graf and Soran 2010; Großschedl et al. 2014) as predictive factors. Just recently, statistical thinking (Fiedler et al. 2019) and the perception of a personal conflict with evolution (Sbeglia and Nehm 2020) were demonstrated to influence evolution acceptance. In addition, there are some factors whose relationship with acceptance of evolution has only recently begun to be researched, for instance interest in evolution (Barnes et al. 2021a). These differences in research findings reflect the intensely debated measurement issues in evolution education (Beniermann 2019; Barnes et al. 2019; McCain and Kampourakis 2018; Mead et al. 2019; Nehm and Mead 2019; Novick and Catley 2012; Smith et al. 2016), such as the potential for biased results based on the measurement instruments used (Barnes et al. 2019), neglect of measurement standards (Mead et al. 2019), missing definitions of key constructs (Ha et al. 2021b; Konnemann et al. 2012; McCain and Kampourakis 2018), or a sole focus on natural selection while addressing the multidimensional construct of knowledge about evolution (Kuschmierz et al. 2020a). Most research in evolution education has been conducted in the United States (e.g., Miller et al. 2021), while there is comparably scarce empirical data on evolution acceptance and knowledge in Europe (Kuschmierz et al. 2020b).

Europe's situation is very diverse due to different languages, educational systems, and more fragmented research communities (Deniz and Borgerding 2018). Thus, due to a lack of standardized assessment procedures in the existing literature, a comprehensive overview of knowledge about evolution and acceptance of evolution in Europe based on comparable data is still missing (Kuschmierz et al. 2020b). 


\section{Theoretical background Methodological issues}

Most international comparative surveys measuring acceptance of evolution (Brenan 2019; Hameed 2008; Ipsos Global @dvisory 2011; Miller et al. 2006; Pew Research Center 2015) or knowledge about evolution (European Commission 2005) collected data using only one multiple-choice question with few answer options. These surveys' results may be misleading because of a limited number of answer options (true-false, e.g., in Miller et al. 2006) that forces respondents to choose between few options on a complex topic (Pobiner 2016). Until now, no international comparative study has been performed to compare the state of acceptance of evolution and knowledge about evolution employing a questionnaire, including various multiple-choice questions and rating-scale items (Kuschmierz et al. 2020b).

The distinction between acceptance of evolution and knowledge about evolution in measurement instruments is of crucial importance, since people can have scientifically correct conceptions about evolution but are still not convinced evolution is really happening (McCain and Kampourakis 2018). Another methodological issue is not to distinguish between acceptance of evolution and religious faith (e.g., Clément 2015) because the way in which the relationship of faith, evolution, and creationism is presented influences survey results (Elsdon-Baker 2015; Kampourakis and Strasser 2015).

The sole focus of several of these comparative surveys on human evolution (e.g., in Brenan 2019; Pew Research Center 2015) may lead to another bias as human evolution is known to be harder to accept (Barnes et al. 2019) and causes higher discomfort (Grunspan et al. 2021; Rughiniş 2011) than evolution of animals and plants. Sbeglia and Nehm (2020) demonstrated that personal conflict with evolution in particular impacts acceptance of human evolution.

Also, definitions of key constructs in previous studies like knowledge, understanding, attitudes, and acceptance are inconsistent and lead to different operationalizations (Ha et al. 2021b; McCain and Kampourakis 2018; Smith et al. 2016). This ambiguous use of terms could be one of the main reasons for partially contradicting results in this field of research (Konnemann et al. 2012; Mead et al. 2019; Smith et al. 2016). For example, 'acceptance' is described as belief, an affective attitude, or a cognitive construct (Konnemann et al. 2012).

'Acceptance of evolution' is the central construct of this work and describes a positive attitude towards evolution (American Educational Research Association 1999). We use the term 'attitude' to describe a connection between an entity (attitude object), and its subjective evaluation (Eagly and Chaiken 1993). Thus, an 'attitude towards evolution' describes personal evaluations about the statement that evolution occurs. A positive attitude towards evolution is called 'acceptance,' while a negative attitude is called 'rejection' (Ingram and Nelson 2006).

In our terminology, we use the term 'knowledge' instead of the common term 'understanding' because we decided to survey content knowledge. The design of this study (using quantitative methods with a large sample size) is not suitable for measuring understanding. This distinction between terms follows the definition that a "student gains knowledge (via instruction, self-study, etc.) upon which she can build understanding" (Smith and Siegel 2016).

\section{Evolution knowledge and acceptance in Europe}

Much research in evolution education has been conducted in the United States (Miller et al. 2021), possibly due to the predominant public opposition to evolution (Brenan 2019) and the long history of creationism in the country (Scott 2008). In contrast, respondents of European countries have shown comparably high acceptance of evolution (European Commission 2005; Miller et al. 2006).

Nevertheless, there are reasons for comparing European countries in a standardized way. Europe's situation is unique because of many countries in geographically little space. Additionally, European countries differ due to different languages, educational systems, and fragmented research communities (Deniz and Borgerding 2018; Kuschmierz et al. 2020b). Thus, investigating differences of knowledge about evolution and acceptance of evolution in Europe based on comparable data offers new insights for the international research community. To date, only few international comparative studies measuring acceptance of evolution or knowledge about evolution in many different countries have been performed in Europe (Clément 2015; Miller et al. 2006). Due to a lack of standardized assessment procedures in the existing literature (Kuschmierz et al. 2020b), previous results should be used with caution when trying to compare European countries as there are several limitations.

The body of existing research on evolution knowledge and acceptance in Europe also varies between both the education levels and the countries. Only in Germany, Greece, and Turkey, more than three studies on knowledge about evolution have been published between 2010 and 2020 (Kuschmierz et al. 2020b). In the same period, only five European cross-country studies on knowledge about evolution have been published, comparing two (Göransson et al. 2020; Graf and Soran 2010; Kralj et al. 2018; Pinxten et al. 2020) to four (Šorgo et al. 2014) European countries. And, there are even less studies (Clément 2015; Graf and Soran 2010) that compared samples from 
more than one country regarding acceptance of evolution. Between 2010 and 2020, only in four European countries (Germany, Greece, Turkey, and the United Kingdom) three or more studies on acceptance of evolution have been published (Kuschmierz et al. 2020b).

These findings indicate a research gap in Europe in terms of comparable results on evolution knowledge and acceptance in a clearly defined target group.

\section{Relationship of evolution knowledge, acceptance, and religious faith}

For decades, the science education research community has investigated how evolution knowledge and acceptance are related to each other and still there is no consensus about this relationship (Barnes et al. 2019; Dunk et al. 2019; Glaze and Goldston, 2015). Whereas some studies reveal a strong ( $\mathrm{Ha}$ et al. 2015; Rutledge and Warden 2000; Trani 2004), or a moderate to weak positive correlation between these factors (Akyol et al. 2012; Athanasiou et al. 2012; Fiedler et al. 2019; Graf and Soran 2010; Großschedl et al. 2014; Ha et al. 2019; Nadelson and Sinatra 2009), other studies report no connection between knowledge and acceptance of evolution (Akyol et al. 2010; Athanasiou et al. 2016; Bishop and Anderson 1990; Sinatra et al. 2003; Tekkaya et al. 2012). However, primary and secondary education students often demonstrated a lacking or weak correlation between acceptance and knowledge (Kuschmierz et al. 2020b), while in most studies pre- and in-service teachers showed a moderate (e.g., Deniz and Sahin 2016) or weak (e.g., Großschedl et al. 2014) positive relationship between these variables.

Previous research in Europe revealed that religious faith and acceptance of evolution are closely related in respondents of various education levels, indicating a lower acceptance with increasing religious faith (Athanasiou et al. 2016; Betti et al. 2020; Clément et al. 2012; Deniz and Sahin 2016; Eder et al. 2011). However, previous research on the relationship between religious faith and acceptance of evolution is limited to few European countries (Kuschmierz et al. 2020b). These studies furthermore indicated differences in acceptance for diverse religious denominations (e.g., Beniermann 2019; Konnemann et al. 2016; Southcott and Downie 2012). A comprehensive European investigation of the relationship between the factors 'knowledge about evolution', 'acceptance of evolution', and 'religious faith' as well as the influence of religious denominations and differences between European countries does not exist.

\section{Study goals}

The target of this research is to investigate evolution acceptance and knowledge and their relationship using the same standardized measuring method across Europe.
Our results provide information on the state of knowledge and acceptance of European students who have recently completed upper secondary education. Furthermore, this study investigates various predictors for acceptance of evolution. In the discussion, we aim to contextualize the findings by providing an overview of European school curricula regarding the extent to which they cover evolutionary biology (Additional file 2).

\section{Research questions}

1. What is the level of knowledge about evolution, acceptance of evolution, and religious faith in European first-year university students in biology and non-biology programs?

2. What is the relationship of knowledge about evolution, acceptance of evolution, and religious faith in European first-year university students in biology and non-biology programs?

3. What are the main factors influencing acceptance of evolution in European first-year university students?

\section{Materials and methods}

Research instrument

For the purpose of this study, we used parts of the "Evolution Education Questionnaire (EEQ)" (Beniermann et al. 2021b) which has been designed to assess acceptance of evolution, knowledge about evolution, and religious faith. Specifically, we analyzed the subscales KAEVO-A (Kuschmierz et al. 2020a), ATEVO (Beniermann 2019), and PERF (Beniermann 2019) of the EEQ. Unlike most instruments in this field of research (Kuschmierz et al. 2020a) - these have been validated in the European context based on standards for educational and psychological testing (American Educational Research Association 1999), as discussed in the "Validity and reliability" section. Categories to enable the standardized interpretation of the results are available for all three instruments (Beniermann et al. 2021b; Kuschmierz et al. 2020a).

\section{Knowledge about evolution}

The Knowledge About Evolution 2.0 instrument (KAEVO 2.0; Kuschmierz et al. 2020a) covers the most essential evolutionary topics, including microevolution and macroevolution. This version, and also its predecessor KAEVO 1.0, were used to measure knowledge about evolution in previous studies (KAEVO 1.0; Beniermann 2019, KAEVO 2.0; Kuschmierz et al. 2020a, Torkar and Šorgo 2020). The instrument consists of three sections (A, B, and C).

KAEVO-A was utilized in this paper and contains 12 multiple-choice items on evolutionary adaptation and 
natural selection (four items), biological fitness (one item), speciation including variation (two items), the heredity of phenotype changes (two items), human evolution (one item), and phylogenetic tree reading (two items). All of these items consist of a question (e.g., "How did the ability to run fast evolve in cheetahs?") embedded in a scenario, followed by several answer options. The answering options contain distractors that reflect common misconceptions, as well as the scientifically correct option. We dichotomized the items of KAEVO-A (correct $=1$; wrong $/$ not known $=0$ ) to generate sum scores for the analyses (score range: 0-12). According to our definition of the construct 'knowledge about evolution', a higher score means a greater knowledge about evolution.

\section{Acceptance of evolution}

The Attitudes Towards Evolution scale (ATEVO; Beniermann 2019; Beniermann et al. 2021b) is a five-point rating scale with eight items. Each item consists of a statement (e.g., "In my personal opinion, the animals and plants we know today have developed from earlier species.") and the five answer options are "agree", "somewhat agree", "undecided", "somewhat disagree", and "disagree." Answers are quantified by values from 1 (absolute rejection of evolution) to 5 (absolute acceptance of evolution). Total scores range between 8 (absolute rejection of evolution) and 40 (absolute acceptance of evolution) (Beniermann et al. 2021b). This is in accordance with our previous definition of the construct 'acceptance of evolution.'

To ensure content validity of the ATEVO experts from different fields have reviewed and evaluated the items (Beniermann 2019). Pre-tests with high school and university students were conducted to ensure the validity of the answer processes (American Educational Research Association 1999). Evidence for local validity and reliability for the ATEVO scale was shown based on four studies $\left(n_{\text {total }}=9311\right.$; Beniermann 2019). Survey populations differed in the four studies to ensure that the ATEVO scale is a suitable instrument to measure attitudes towards evolution for the general public and groups of various ages and education, as well as explicitly non-religious or religious people. In order to address these diverse groups, the ATEVO scale includes items on evolution of plants and animals as well as items with a focus on human evolution that are known to be harder to accept (Barnes et al. 2019). This approach is especially useful when surveying the partly rather secular samples from different European countries (Beniermann et al. 2021b).

\section{Religious faith}

The Personal Religious Faith scale (PERF; Beniermann 2019; Beniermann et al. 2021b) is a five-point rating scale with ten items. Each item consists of a statement (e.g., "I feel that God exists.") and five answer options from "agree" to "disagree". Answers are quantified by values from 1 (not religious) to 5 (very religious), while total scores range between 10 (not religious) and 50 (very religious) (Beniermann et al. 2021b). The PERF scale, based on the same measurement standards and procedure as described above for the ATEVO scale, produces valid and reliable results (Beniermann 2019). It was created to measure religious faith independent from the respondents' denomination (Beniermann 2019).

\section{Additional factors}

In addition to the three main scales of this study, participants had to provide information on their age, sex, interest in biology as well as their denomination. Interest in biology was measured with a rating scale item. Participants were asked to rate their individual interest in biology on a 7-point scale from "very low" to "very high". To indicate their denomination, participants were asked to choose one of the following: Orthodox, Catholic, Christian free churches, Protestant, Muslim (Sunni, Alevi, or Shiite), Jewish, Hindu, Buddhist, Other, or None.

\section{Sample}

We aimed for a broad sample of European University students, including as many European countries as possible, to cover the diversity of Europe. In order to handle the varying total numbers of students in different European countries, a minimum sample size of $n=150$ was negotiated with stakeholders in smaller European countries. As a stratified sampling strategy was not possible due to practical reasons of the national stakeholders, we applied a convenience sampling strategy to also include small European countries as well as less research-intensive countries.

In total, 11,723 first-year university students from 26 European countries voluntarily participated in the study. We chose first-year university students who had recently finished upper secondary education to generate a comparable target group. To learn about the status of knowledge about evolution and acceptance of evolution of students after finishing secondary education in Europe, first-year university students are a suitable sample that is easy to access. The alternative option to survey high school students was not feasible, since the access was not possible in all countries, for instance because high school students have to take important exams in the last weeks of school. Surveying high school students would have decreased the sample size and the number of participating countries substantially.

We excluded all participants who were not enrolled in the first semester, were older than 25 years or graduated 


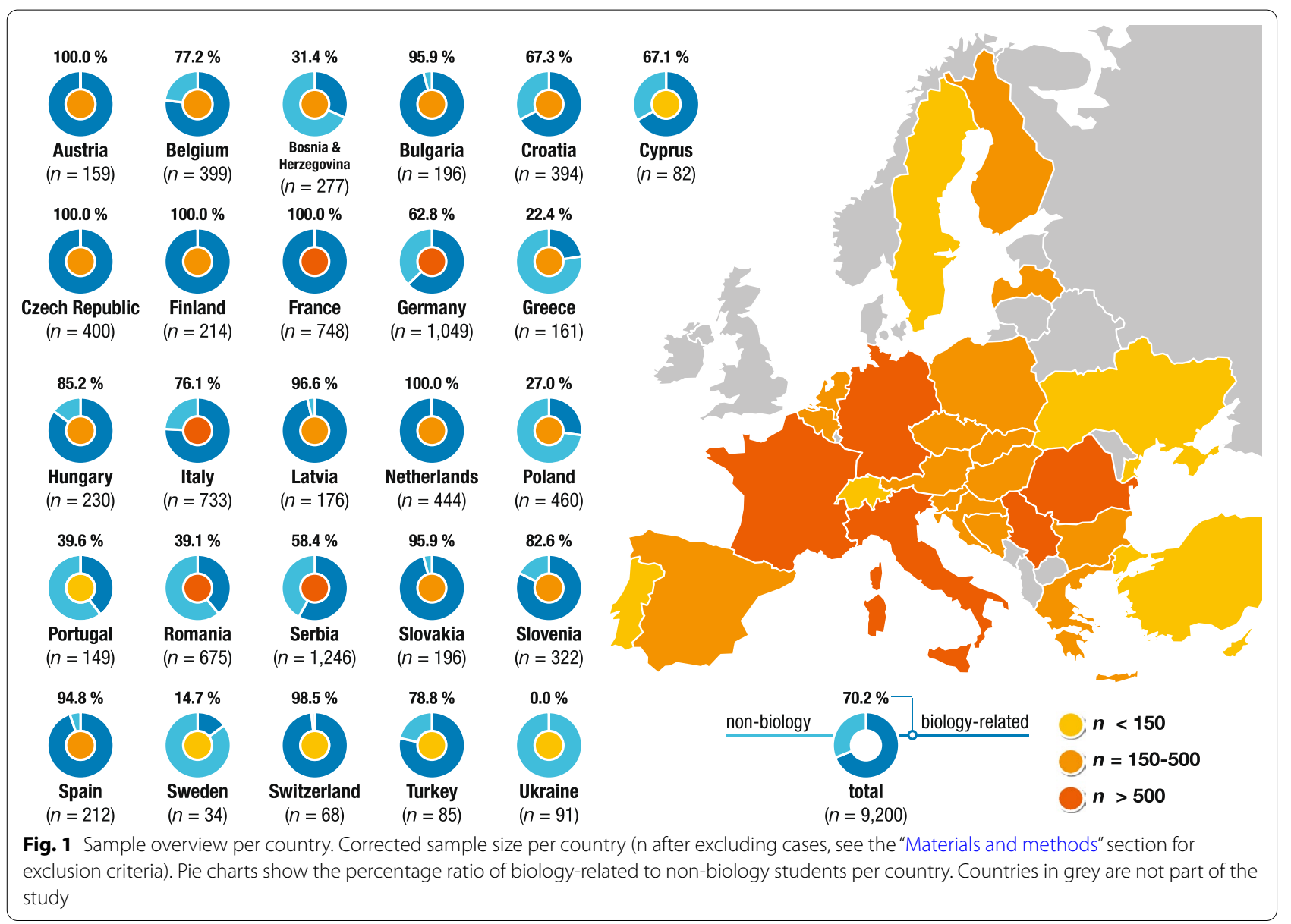

from upper secondary education more than 2 years before the survey. Additionally, participants who spent 2 or more years in a country other than the surveyed country while in upper secondary education were excluded before the analyses. The resulting sample size after exclusion was 9200 (see Fig. 1). We targeted students enrolled in a biology-related university program but also surveyed non-biology students for comparison (list of biologyrelated university programs in Additional file 1).

\section{Data collection}

The English version of the instrument was translated into the participating countries' local languages-23 in total. We ensured the translations' quality by reverse translation of the questionnaire via national experts in the field of biology or biology education. The data were collected at European universities $(N=84)$ at the beginning of the respective semesters/terms. We used a paper-pencil format because we wanted the voluntary respondents to fill the questionnaire in a standardized way in class, lasting about $30 \mathrm{~min}$. The students were supervised while filling out the questionnaire and could not search the internet for the correct answers (in terms of knowledge about evolution) or let others fill out the questionnaire for them. The complete test process was anonymous, and the questionnaire was voluntary; the respondents received no incentives for completing it. Employing uniform survey instructions, the people handing out the questionnaires to students received clear instructions for the respondents, including not to communicate with the respondents beyond the instructions.

For data analysis, we separated the biology-related and non-biology students. This made it possible to compare the results of the respective subgroups in different European countries.

\section{Overviews of the subject 'Biology' and the topic evolution in the European school curricula}

To discuss the results in context and to give additional information to international readers, we reviewed the national school curricula concerning the subject "Biology" of the participating European countries, focusing on the teaching of evolution (see Additional file 2). We then summarized whether and to what extent evolution 
is taught in lower and upper secondary level and which evolutionary concepts are covered.

\section{Statistical analyses}

All statistical analyses were conducted in RStudio (Version 1.3.107 based on R Version 4.0.2). The dataset (Additional file 3), as well as the R-Script (Additional files 4, 5 and 6), can be assessed in the additional information.

In the first step of the data cleaning procedure, we excluded 234 observations from the data set, all belonging to three Spanish courses that were not provided with the questions regarding their religious faith.

With the remaining data set $(n=9200)$, a missing value analysis was conducted. The percentage of missing values across the 41 items varied between 0 and $7.2 \%$. In total 6579 observations were complete (71.5\%). Another 1235 observations had only one missing value (13.4\%), which, after further analyses, we assumed to occur completely at random. In contrast, 559 participants $(6.1 \%$ observations) had not answered any questions concerning their religious faith, despite being provided with the complete questionnaire. We assumed a systematic pattern of missing values for this.

Considering the missing value analysis results, we decided to include all available descriptive studies and scale comparison. Furthermore, we utilized a complete case approach to perform multilevel analyses. Also, we applied the predefined exclusion criteria to filter the original dataset, setting a minimal sample size per country $(n=150)$ to enable statistical analyses in which subgroups are compared (e.g., students of different countries). Six of 26 countries were excluded from the multilevel analyses because the sample size was too small (see countries marked in yellow in Fig. 1). We reported the specific sample size for each analysis.

Mean scores and standard deviations for the three main scales were computed for the entire sample and depending on the country, university program, and sex. To compare the mean scores of knowledge about evolution, acceptance of evolution, and religious faith between students who enrolled in a biology-related university program and students who enrolled in another program, three separate $t$-tests were computed, each based on a mixed model using the country as a random effect and Satterthwaite approximation. The effect size was reported as the difference in explained variance (Aiken et al. 1991). In addition, bivariate correlations for the whole sample were used to describe the relationship between the main scales.

To compare the distributions of the sample values for acceptance of evolution, knowledge about evolution, and religious faith in the whole sample, we rescaled from the original values of the main scales to an artificial scale, ranging from 0 to 100 , using the following equation:

$$
y=\left(\frac{x-x_{\min }}{x-x_{\max }}\right) * 100
$$

Due to our data's hierarchical structure-students are nested in courses at universities within countries-we decided to use a multilevel modeling approach to investigate the relationship between acceptance of evolution and other variables in this dataset. However, the university-specific and country-specific sample sizes are sometimes limited, and multilevel regression models require a certain number of higher-level-units to produce unbiased parameter estimates (McNeish and Stapleton 2016; Snijders 2005). Therefore, we decided to consider only two levels: students as individual observations nested within countries.

We specified an intercept-only model as the null model and five models with an increasing number of fixed effects: Model 1 (sex and age), Model 2 (+ university program and interest in biology), Model 3 ( + knowledge about evolution), Model 4 (+religious faith), and Model 5 (+denomination). Additionally, the country was included in each model as a random intercept. The intercept-only model's intraclass correlation coefficient (ICC) was 0.11 , which means that $11 \%$ of the overall variance can be accounted to country-specific effects $\left(\chi^{2}(1\right.$, $N=6227)=520.65, p<0.001)$ and a multilevel modeling approach is appropriate (Maas and Hox 2005).

All models were estimated using the maximum likelihood method (r-Package: lme4; Bates et al. 2015). Parametric bootstrapping (number of samples: 10,000) was applied to obtain confidence intervals for both the parameter estimates of the fixed effects and the variance components. Due to the listwise deletion procedure, all models were estimated with a sample size of $n=6227$ level- 1 units (students) and $n=20$ level- 2 units (countries). Using the same sample for all models allowed us to compare the models directly via likelihood-ratio tests. Additionally, we evaluated and compared the models based on their Akaike information criterion (AIC), Bayesian information criterion (BIC), and Pseudo- $\mathrm{R}^{2}$ values. A decrease in AIC and BIC between two subsequent models indicates a better fit of the latter. $R_{m}^{2}$ (marginal) represents the proportion of variance explained by fixed factors. $R_{c}^{2}$ (conditional) represents the proportion of variance explained by both fixed and random factors (Johnson 2014; Nakagawa and Schielzeth 2013).

We tested the models for multivariate normality of their residuals, as well as for homoscedasticity and multicollinearity. Multicollinearity was not an issue, as the explanatory variables' VIF values ranged between 1 and 1.4. However, the residuals' distribution was significantly left-skewed, and 
visual analyses of the quantile-quantile-plots (QQ-plots) indicated heteroscedastic residuals due to a ceiling effect. We used the package "robustlmm" (Koller 2016) and a Design Adaptive Scale approach to obtain robust parameter estimates and evaluate if the models' parameter estimates vary significantly from the initial non-robust models. We found minimal variations in the parameter estimates and reasonably narrow confidence intervals of the nonrobust models' parameter estimates. Thus, we decided to report the results of the initial models.

Our initial plan was to account for interactions between the explanatory variables and allow the regression slopes for religious faith to vary randomly in two additional models.

As both models either did not converge properly (random slope model) or yielded biased parameter estimates due to multicollinearity (interaction model with VIF scores above 5), we decided to exclude them from the results.

\section{Validity and reliability}

All elements of the EEQ instrument have been validated in an iterative process, and evidence for validity and reliability has been provided in previous studies (Beniermann 2019; Kuschmierz et al. 2020a).

In addition, the KAEVO instrument has been introduced with a four-dimensional structure for KAEVO-A (Kuschmierz et al. 2020a). Factor analysis for the present study sample confirmed this structure.

In previous studies (Beniermann 2019), the ATEVO scale has shown a unidimensional or two-dimensional structure for different samples. Principal Axis Factoring (PAF) for ATEVO and PERF revealed appropriateness to treat each of them as unidimensional (Field 2009; see Table 1).

We tested evidence for the reliability of the scales via internal consistency. The PERF scale produced very high Cronbach's alpha values for the entire sample $(\alpha=0.969)$ and all single countries. The ATEVO scale had a high value for the whole sample $(\alpha=0.739)$ and acceptable-to-high values for the single countries (Table 2).

The KAEVO instrument contains several underlying constructs, which is why Cronbach's alpha is not appropriate to measure the reliability of the entire instrument (Kuschmierz et al. 2020a).

\section{Results}

European first-year university students generally accepted evolution but lacked substantial knowledge about evolution. Moreover, students also varied much more in their knowledge about evolution and religious faith than in their acceptance of evolution

Within the investigated sample, first-year university students across Europe rather accepted evolution

Table 1 Principal Axis Factor loadings of the ATEVO and PERF scale

\begin{tabular}{lllll}
\hline ATEVO & & & \multicolumn{2}{l}{ PERF } \\
\cline { 1 - 1 } Item Nr & Factor loading & & Item $\mathbf{~ r r}$ & Factor loading \\
\hline E1 & 0.49 & F1 & 0.90 \\
E2 & 0.53 & F2 & 0.91 \\
E3 & 0.60 & F3 & 0.85 \\
E4 & 0.45 & F4 & 0.90 \\
E5 & 0.55 & F5 & 0.83 \\
E6 & 0.38 & F6 & 0.82 \\
E7 & 0.68 & F7 & 0.87 \\
E8 & 0.49 & F8 & 0.90 \\
& & F9 & 0.84 \\
& & F10 & 0.86
\end{tabular}

Acceptance of evolution (ATEVO): $n=8737$. Extraction method Principal Axis Factoring. Factor $1=2.23$ (28\% variance). KMO (Kaiser-Meyer-Olkin Test) $=0.79$. Religious faith (PERF): $n=8529$. Extraction method Principal Axis Factoring. Factor $1=7.55$ ( $76 \%$ variance). $\mathrm{KMO}=0.96$

Table 2 Reliability (Cronbach's alpha) of the acceptance of evolution (ATEVO) and religious faith (PERF) scale

\begin{tabular}{lrll}
\hline Countries & $\boldsymbol{N}$ & ATEVO & PERF \\
& & $\boldsymbol{a}$ & $\boldsymbol{a}$ \\
\hline Austria & 159 & 0.751 & 0.958 \\
Belgium & 399 & 0.832 & 0.970 \\
Bosnia and Herzegovina & 277 & 0.697 & 0.974 \\
Bulgaria & 196 & 0.668 & 0.951 \\
Croatia & 394 & 0.780 & 0.975 \\
Czech Republic & 400 & 0.726 & 0.943 \\
Finland & 214 & 0.728 & 0.955 \\
France & 748 & 0.636 & 0.969 \\
Germany & 1049 & 0.747 & 0.959 \\
Greece & 161 & 0.514 & 0.943 \\
Hungary & 230 & 0.768 & 0.967 \\
Italy & 733 & 0.660 & 0.965 \\
Latvia & 176 & 0.709 & 0.951 \\
Netherlands & 444 & 0.854 & 0.961 \\
Poland & 460 & 0.753 & 0.973 \\
Romania & 675 & 0.668 & 0.962 \\
Serbia & 1246 & 0.745 & 0.964 \\
Slovakia & 196 & 0.614 & 0.958 \\
Slovenia & 322 & 0.656 & 0.970 \\
Spain & 212 & 0.602 & 0.969 \\
total & 8691 & 0.739 & 0.969 \\
\hline $\boldsymbol{a}=$ Cronbach's alpha & & &
\end{tabular}


$(M=32.17, S D=4.94$; score range: $8-40$; see Table 3$)$. Biology-related students accepted evolution slightly more $(M=32.52, S D=4.86$; see Table 3$)$ than nonbiology students $(M=31.28, S D=5.01$; score range: 8-40; see Table 3 ) but the effect size was negligible $\left(t(7835.83)=-8.30, p<0.001, f^{2}=0.01\right)$. A small number of students rejected $(0.39 \%)$ or rather rejected $(0.95 \%)$ evolution (according to the suggested categories in Table 4).

In contrast, students generally lacked significant knowledge about evolution, evidenced by the fact that, on average, they answered less than half of the questions in a scientifically accurate manner $(M=5.06, S D=2.57$; score range: $0-12$; see Table 3 ). Students that were recently enrolled in a biology-related university program knew significantly more about evolution $(M=5.53, S D=2.54$; score range: $0-12$; see Table 3 ) than new non-biology students $(M=3.85, S D=2.22$; score range: $0-12$; see Table 3$)$, with a medium effect size $(t(7799.74)=--8.93$, $\left.p<0.001, f^{2}=0.05\right)$. However, even within the group of biology-related students, many demonstrated very low $(47.4 \%)$ or low $(27.1 \%)$ knowledge about evolution (see Table 4).

Overall, students identified as not rather religious $(M=26.78, S D=13.59$; score range: $10-50$; see Table 3$)$. Nevertheless, non-biology students were significantly more religious $(M=30.82, S D=13.30$; score range: 10-50; see Table 3) than biology-related students $(M=25.11, S D=13.36$; score range: $10-50$; see Table 3$)$; however, as with acceptance of evolution, the effect size

Table 3 Descriptive data of the sample

\begin{tabular}{llll}
\hline & Biology-related & Non-biology & Total \\
\hline Acceptance & & & \\
$M$ & 32.52 & 31.28 & 32.17 \\
SD & 4.86 & 5.01 & 4.94 \\
$n$ & 6056 & 2470 & 8527 \\
$t$-test & $-8.30^{* * *}$ & & \\
Knowledge & & & \\
$M$ & 5.53 & 3.85 & 5.06 \\
SD & 2.54 & 2.22 & 2.57 \\
$n$ & 5616 & 2189 & 7806 \\
$t$-test & $-18.93^{* * *}$ & & \\
Religious faith & & & 26.78 \\
$M$ & 25.11 & 30.82 & 13.59 \\
SD & 13.36 & 13.30 & \\
$n$ & 5912 & 2441 & \\
$t$-test & $6.21^{* * *}$ & &
\end{tabular}

Mean $(M)$, standard deviation (SD), and sample size $(\mathrm{n})$ for acceptance of evolution (ATEVO; Beniermann 2019): score range: $8-40$; knowledge about evolution (KAEVO; Kuschmierz et al., 2020a): score range: $0-12$; religious faith (PERF; Beniermann 2019): score range: $10-50 ;{ }^{* * *} p<.0 .001$
Table 4 The percentage share of different categories for knowledge about evolution, acceptance of evolution, and religious faith

\begin{tabular}{|c|c|c|c|}
\hline & \multicolumn{3}{|l|}{ Percentage (\%) } \\
\hline & Biology-related & Non-biology & Total \\
\hline \multicolumn{4}{|l|}{ Acceptance } \\
\hline Acceptance (35-40) & 36.5 & 27.7 & 34.0 \\
\hline Rather acceptance (29-34) & 44.5 & 45.1 & 44.7 \\
\hline Indifferent position (20-28) & 17.7 & 25.4 & 19.9 \\
\hline Rather rejection (14-19) & 0.9 & 1.2 & 1.0 \\
\hline Rejection (8-12) & 0.3 & 0.5 & 0.4 \\
\hline$n$ & 6065 & 2470 & 8526 \\
\hline \multicolumn{4}{|l|}{ Knowledge } \\
\hline High knowledge (12) & 0.1 & 0.0 & 0.1 \\
\hline $\begin{array}{l}\text { Rather high knowledge } \\
(10-11)\end{array}$ & 4.2 & 0.8 & 0.3 \\
\hline Moderate knowledge (8-9) & 21.2 & 6.3 & 17.0 \\
\hline Low knowledge (6-7) & 27.1 & 16.6 & 24.1 \\
\hline Very low knowledge (0-5) & 47.4 & 76.3 & 55.5 \\
\hline$n$ & 5616 & 2189 & 7805 \\
\hline \multicolumn{4}{|l|}{ Religious faith } \\
\hline Very religious (43-50) & 15.0 & 24.7 & 17.8 \\
\hline Religious (35-42) & 12.9 & 19.9 & 14.9 \\
\hline Indifferent position (26-34) & 17.5 & 20.6 & 18.4 \\
\hline Not religious (18-25) & 14.1 & 10.5 & 13.1 \\
\hline Not religious at all (10-17) & 40.5 & 24.3 & 35.7 \\
\hline$n$ & 5912 & 2441 & 8353 \\
\hline
\end{tabular}

Acceptance of evolution (ATEVO; Beniermann 2019): score range: 8-40; knowledge about evolution (KAEVO; Kuschmierz et al. 2020a): score range: 0-12; religious faith (PERF; Beniermann 2019): score range: 10-50. Displayed are shares within categories (Beniermann 2019; Kuschmierz et al. 2020a) of ATEVO, KAEVO, and PERF

was negligible $\left(t(8296.66)=6.21, p<0.001, f^{2}=0.01\right)$. The majority of students were not religious at all $(35.7 \%$; see Table 4).

We used scaled values to standardize the different score ranges and visualize the distribution of responses (see Fig. 2). Comparing these distributions illustrated clear differences between acceptance of evolution, knowledge about evolution, and first-year university students' religious faith. Whereas few students did not accept evolution in both subgroups, the scope of knowledge about evolution was broadly distributed. The two subgroups differed most regarding their knowledge about evolution. Students with high and moderate religious faith were equally represented in the biology-related subgroup, while most students were not religious. Non-biology students with high, moderate, and low religious faith also roughly balanced each other. Still, compared to the biology-related students, there were fewer students who are not religious. 


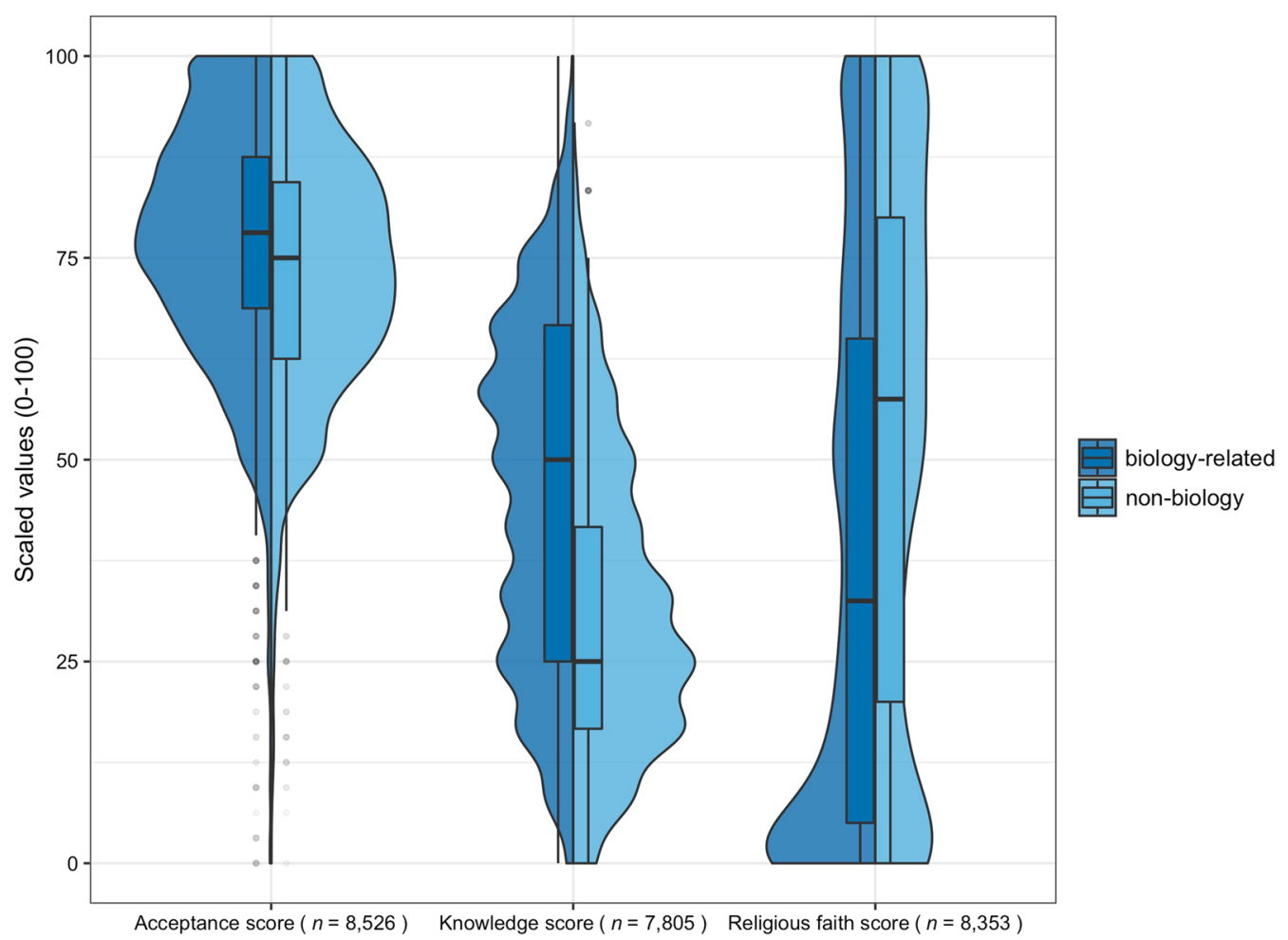

Fig. 2 Student subgroup scores for acceptance of evolution, knowledge about evolution, and religious faith. Scaled values for the entire subgroup samples are displayed. Low scores correspond to low acceptance, low knowledge, and low religious faith. Black bars represent median scores. Boxes represent Q1 and Q3 (IQR). Whiskers represent minima and maxima. Dots represent outliers. Subgroup 1 (left half of the violin plots): biology-related students; Subgroup 2 (right half of the violin plots): non-biology students. Biology-related students: acceptance of evolution, $n=6056$,

$M_{\text {scaled }}=76.64, S D=15.20 ;$ knowledge about evolution, $n=5616, M_{\text {scaled }}=46.10, S D=21.18$; religious faith, $n=5912, M_{\text {scaled }}=37.78, S D=33.41$. Non-biology students: acceptance of evolution, $n=2,470, M_{\text {scaled }}=72.76, S D=15.66 ;$ knowledge about evolution, $n=2189, M_{\text {scaled }}=32.09$, $S D=18.49$; religious faith, $n=2441, M_{\text {scaled }}=52.05, S D=33.25$

Students with a lower acceptance of evolution also showed less knowledge about evolution but higher religious faith. Knowledge and acceptance were only weakly related In our sample, acceptance of evolution (ATEVO score) and religious faith (PERF score) showed significantly negative correlations with a moderate effect.

$\left(r_{\text {ATEVO-PERF }}=-0.37, p<0.01\right.$; see Fig. 3). Similarly, knowledge about evolution (KAEVO score) and religious faith showed significantly negative correlations with a moderate effect $\left(r_{K A E V O-P E R F}=-0.36, p<0.01\right.$; see Fig. 3). In contrast, knowledge about evolution and acceptance of evolution showed significantly positive correlations with a weak effect $\left(r_{\text {KAEVO- ATEVO }}=0.29\right.$, $p<0.01$; see Fig. 3).

At the country level, the samples did not differ much in acceptance of evolution but varied much more in knowledge about evolution and religious faith (see Fig. 4). Finland (100\% bio-related students), the Netherlands (100\% biology-related students), and Spain (94.8\% biology-related students) showed the highest scores in knowledge about evolution (see Fig. 4). Furthermore, in 19 of 26 countries, students answered less than half of the questions on knowledge about evolution correctly (see Table 5).

\section{Among European first-year university students,} the country of residence had only a minimal impact on acceptance of evolution. In addition, the extent of religious faith influenced acceptance of evolution much more than knowledge about evolution

A multilevel modeling approach was used to account for variations in acceptance of evolution between students (Level 1) and countries (Level 2). The following explanatory variables were added sequentially: age, sex, enrollment in a biology-related university program (yes/no), 


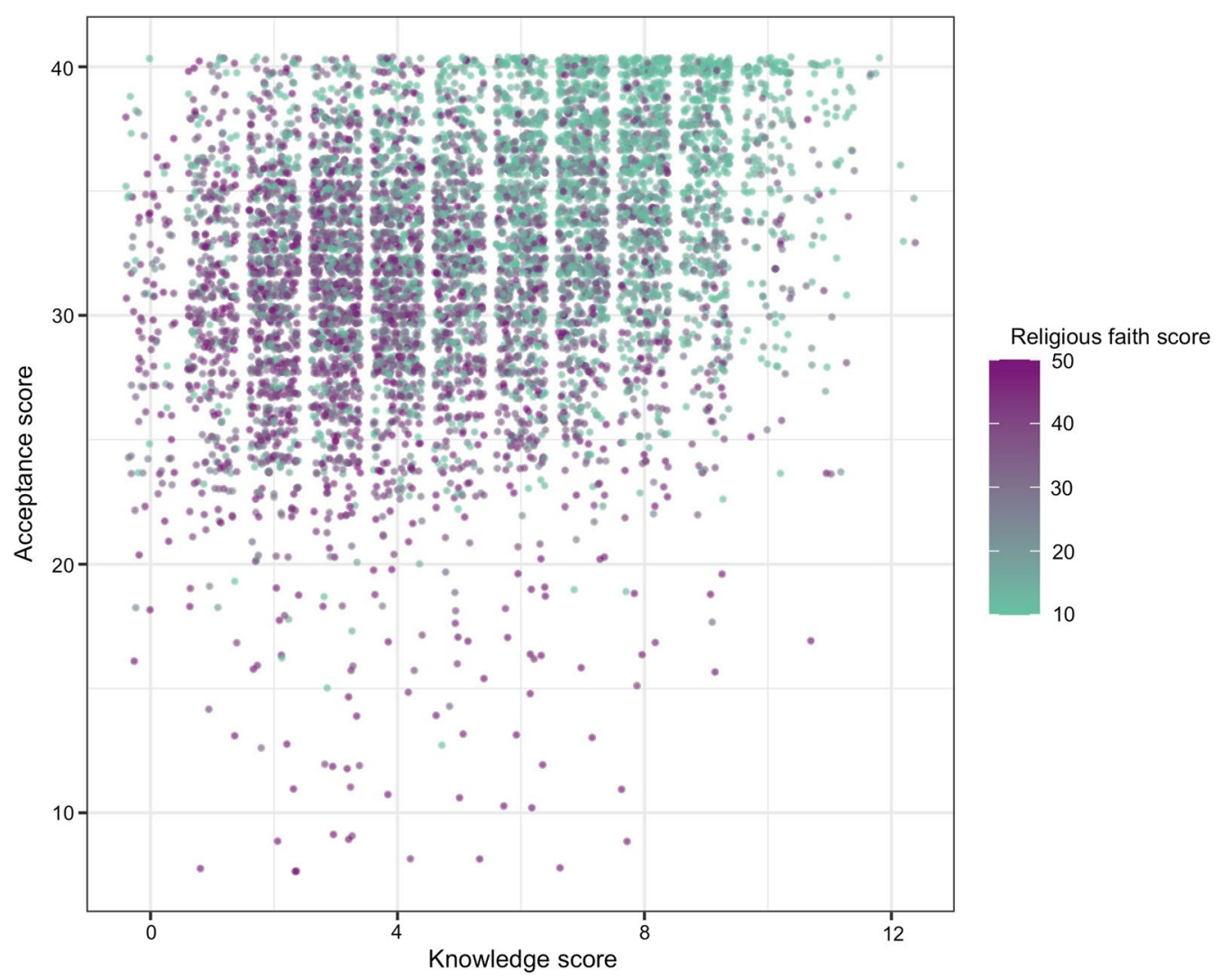

Fig. 3 Relationships between knowledge about evolution, acceptance of evolution, and religious faith. Scores (for each student) for knowledge about evolution (KAEVO score range: $0-12$ ), acceptance of evolution (ATEVO score range: 8-40), and religious faith (PERF score range: 10-50) are displayed. Low scores correspond to low knowledge, low acceptance, and low religious faith. $r_{\text {ATEVO-PERF }}=-0.37^{* *}, n=8032 ; r_{\text {KAEVO-PERF }}=-0.36^{* *}$, $n=7260 ; r_{\text {KAEVO-ATEVO }}=0.29^{* *}, n=7434 ;{ }^{* *}$ Correlation is significant at the 0.01 level (2-tailed)

interest in biological topics, knowledge about evolution, religious faith, and denomination (see Table 6).

Overall, Model 4, which included the explanatory variables age, sex, enrolled in a biology-related university program, interest in biological topics, knowledge about evolution, and religious faith, provided the best model fit. It explained significantly more variance in acceptance of evolution (23\%) than all previous models. In Model 4, 19\% of the explained variance could be attributed to the explanatory variables. The largest proportion of variance explained could be attributed to religious faith, as Model 4 explained $11 \%$ more variance than Model $3\left(\chi^{2}(1, N=6227)=611.62, p<0.001\right)$.

The model showed that very religious students accepted evolution significantly less than non-religious students. Furthermore, with each unit increase on the religious faith scale, the acceptance of evolution score dropped by 0.12 units $(b=-0.12, p<0.001,95 \%$ CI $[-0.12,-0.11])$.

Also, there was a significant relationship between knowledge about evolution and acceptance of evolution $(b=0.24, p<0.001,95 \%$ CI $[0.19,0.29])$, indicating that students who knew more about evolution also tended to accept evolution more.

The increase in variance explained by adding knowledge about evolution in Model 3 was $4 \%\left(x^{2}(1\right.$, $N=6227)=169.81, \quad p<0.001)$. The decrease of the parameter estimate for knowledge about evolution between Model 3 and Model 4 indicated that some of the variance explained by knowledge about evolution may be related to the extent of the students' religious faith.

Acceptance of evolution by students increased with their interest in biological topics. An increase in interest in biological topics by one unit accompanied an increase in acceptance of evolution by 0.32 units $(b=0.32, p<0.001$, $95 \%$ CI $[0.23,0.41])$. As a variable, interest in biological topics seemed to be more or less independent from the other investigated explanatory variables, and its estimated effect was rather stable across all models. Whether a student enrolls in a biology-related university program was not a significant predictor for acceptance of evolution (Model 4). Model 2 showed that students enrolled in a 

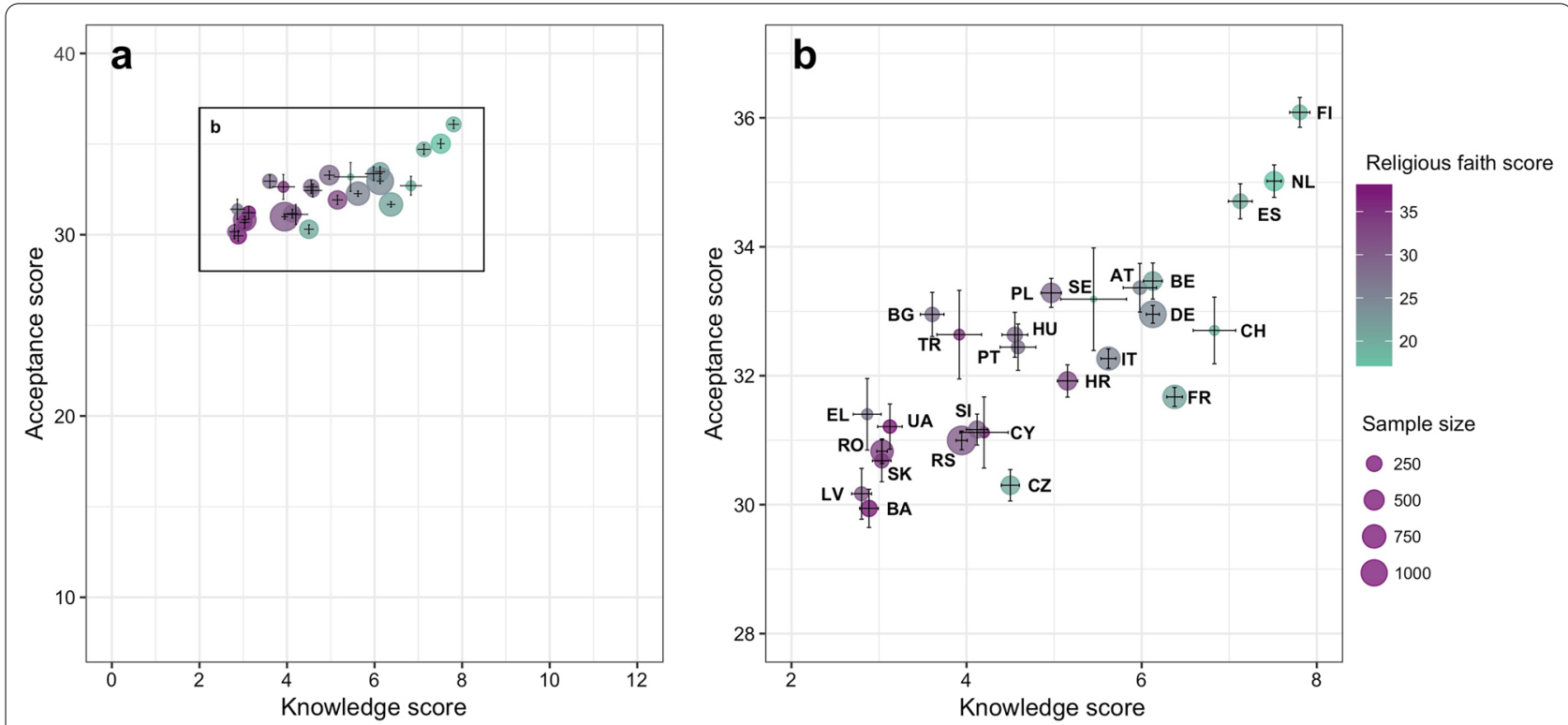

Fig. 4 Variables' relationships per country (a full score ranges; $\mathbf{b}$ only sections of the score ranges). In $\mathbf{a}$, mean scores (for all students of each country) for knowledge about evolution (KAEVO score range: 0-12), acceptance of evolution (ATEVO score range: 8-40), and religious faith (PERF score range: 10-50) are displayed. In b, only sections of the score ranges (Knowledge score: 2-8; Acceptance score: 28-37) are displayed to make the cross-country differences in knowledge about evolution and religious faith more evident. Low scores correspond to low knowledge, low acceptance, and low religious faith. Error bars represent standard errors. Austria: AT, Belgium: BE, Bosnia-Herzegovina: BA, Bulgaria: BG, Croatia: HR, Cyprus: CY, Czech Republic: CZ, Finland: Fl, France: FR, Germany: DE, Greece: EL, Hungary: HU, Italy: IT, Latvia: LV, Netherlands: NL, Poland: PL, Portugal: PT, Romania: RO, Serbia: RS, Slovakia: SK, Slovenia: SI, Spain: ES, Sweden: SE, Switzerland: CH, Turkey: TR, Ukraine: UA

biology-related study program tended to accept evolution more than students enrolled in a non-biology program. However, when adding knowledge about evolution to the model, the effect of the students' program decreased (Model 3).

Female students accepted evolution significantly less $(b=-0.59, p<0.001,95 \%$ CI $[-0.84,-0.35])$ than male students for all models. However, the effect's strength decreased when adding the variables knowledge about evolution (Model 3) and religious faith (Model 4). This indicated that some of the variances in acceptance of evolution between men and women could be accounted for by sex differences in knowledge about evolution and religious faith rather than sex itself. As expected in this age-homogeneous target group (see exclusion criteria in the "Sample" section), age was not a significant predictor across all four models.

In general, a students' denomination was also not a significant predictor for acceptance of evolution. Model 5 explained only negligibly more variance than Model 4 $\left(\chi^{2}(1, N=6227)=43.51, p<0.001\right)$ and Model 4 showed the better model fit, indicated by the BIC (Table 5 ). However, acceptance of Protestants $(b=-0.67, p<0.01$, 95\% CI $[-1.18,-0.19])$ and Muslims $(b=-1.91$, $p<0.001,95 \%$ CI $[-2.78,-1.00])$ was significantly lower than for students without a denomination.

In the best-fitting Model 4, a country's affiliation explained variance dropped to $5 \%(\mathrm{ICC}=0.05)$. This may indicate an interaction between the Level-1 and Level-2 explanatory variables. As our study's focus was confined to individual explanatory variables on acceptance of evolution and not country-specific factors, we did not gather additional information.

\section{Discussion}

Within the group of European first-year university students, country affiliation plays only a minimal role in accepting evolution

We provided the first standardized comparative analysis on the state of evolution knowledge and acceptance in Europe and the role of the country affiliation based on a clearly defined and comparable target group. For the first time, to our knowledge, European students were surveyed regarding their evolution knowledge and acceptance using the same multidimensional measuring instrument. Our results show that European first-year university students mostly accept evolution. The country affiliation plays only a minimal role in explaining 
Table 5 Scores for acceptance of evolution, knowledge about evolution, and religious faith per country

\begin{tabular}{|c|c|c|c|c|c|c|c|c|c|}
\hline \multirow[t]{2}{*}{ Country } & \multicolumn{3}{|c|}{ Acceptance of evolution } & \multicolumn{3}{|c|}{ Knowledge about evolution } & \multicolumn{3}{|c|}{ Religious faith } \\
\hline & $M$ & $S D$ & $N$ & $M$ & $S D$ & $N$ & $M$ & $S D$ & $N$ \\
\hline Austria & 33.37 & 4.75 & 156 & 5.98 & 2.41 & 145 & 24.47 & 12.64 & 155 \\
\hline Belgium & 33.47 & 5.59 & 384 & 6.13 & 2.16 & 377 & 20.63 & 12.35 & 392 \\
\hline Bosnia-Herzegovina & 29.94 & 4.92 & 222 & 2.89 & 1.78 & 184 & 38.13 & 12.73 & 210 \\
\hline Bulgaria & 32.95 & 4.80 & 184 & 3.61 & 1.88 & 148 & 27.77 & 12.79 & 178 \\
\hline Croatia & 31.92 & 4.97 & 373 & 5.15 & 2.30 & 353 & 32.73 & 14.01 & 350 \\
\hline Cyprus & 31.12 & 4.99 & 75 & 4.2 & 2.51 & 70 & 38.01 & 9.95 & 74 \\
\hline Czech Republic & 30.30 & 4.87 & 363 & 4.5 & 2.04 & 360 & 20.12 & 10.68 & 376 \\
\hline Finland & 36.09 & 3.38 & 200 & 7.81 & 1.69 & 191 & 18.54 & 9.98 & 203 \\
\hline France & 31.67 & 4.01 & 681 & 6.38 & 1.69 & 620 & 21.06 & 12.31 & 664 \\
\hline Germany & 32.95 & 4.45 & 979 & 6.13 & 2.41 & 879 & 24.36 & 12.03 & 972 \\
\hline Greece & 31.21 & 4.45 & 152 & 3.13 & 1.78 & 144 & 37.75 & 10.69 & 153 \\
\hline Hungary & 32.64 & 5.30 & 222 & 4.55 & 2.24 & 212 & 28.04 & 13.76 & 207 \\
\hline Italy & 32.27 & 4.05 & 695 & 5.62 & 2.32 & 656 & 25.18 & 11.84 & 648 \\
\hline Latvia & 30.17 & 5.24 & 166 & 2.80 & 1.50 & 141 & 31.55 & 12.38 & 172 \\
\hline The Netherlands & 35.02 & 5.30 & 431 & 7.51 & 1.71 & 409 & 17.11 & 10.23 & 430 \\
\hline Poland & 33.29 & 4.82 & 427 & 4.97 & 2.48 & 397 & 28.42 & 14.26 & 431 \\
\hline Portugal & 32.44 & 4.39 & 140 & 4.59 & 2.49 & 136 & 27.83 & 12.81 & 139 \\
\hline Romania & 30.83 & 4.98 & 605 & 3.03 & 1.56 & 544 & 33.68 & 12.60 & 592 \\
\hline Serbia & 31.00 & 5.11 & 1135 & 3.94 & 2.25 & 990 & 30.96 & 12.75 & 1068 \\
\hline Slovakia & 30.68 & 4.55 & 188 & 3.03 & 1.49 & 186 & 34.48 & 13.04 & 183 \\
\hline Slovenia & 31.16 & 4.31 & 298 & 4.12 & 2.20 & 257 & 29.53 & 13.20 & 300 \\
\hline Spain & 34.71 & 3.97 & 204 & 7.13 & 1.98 & 190 & 20.02 & 12.16 & 204 \\
\hline Sweden & 33.19 & 4.64 & 32 & 5.45 & 2.19 & 31 & 17.56 & 10.93 & 32 \\
\hline Switzerland & 32.70 & 4.26 & 64 & 6.83 & 2.00 & 59 & 18.88 & 10.01 & 66 \\
\hline Turkey & 32.64 & 6.33 & 69 & 3.92 & 2.35 & 60 & 35.25 & 13.86 & 71 \\
\hline Ukraine & 31.40 & 5.30 & 82 & 2.87 & 1.52 & 67 & 27.04 & 13.46 & 83 \\
\hline
\end{tabular}

Score ranges: acceptance of evolution: 8-40; knowledge about evolution: 0-12; religious faith: 10-50

acceptance or rejection of evolution. These two findings indicate that most of the European education systems for upper secondary education with all their differences lead to acceptance of evolution at least in university students. So far, studies showed varying results, depending on the used instrument or the surveyed country. Results of some previous studies on university students of different European countries are supported by our findings (Arthur 2013; Beniermann 2019; Betti et al. 2020; European Commission 2005; Gefaell et al. 2020; Graf and Soran 2010; Großschedl et al. 2014; Konnemann et al. 2018; Nehm et al. 2013; Southcott and Downie 2012). However, other studies revealed undecided positions or rejection of evolution among pre-service teachers in Greece (Athanasiou et al. 2012; Athanasiou and Papadopoulou 2012) and Turkey (Akyol et al. 2010, 2012; Bilen and Ercan 2016; Deniz et al. 2011; Deniz and Sahin 2016; Graf and Soran 2010; Irez and Bakanay 2011; Yüce and Önel 2015). In the present study, Greek and Turkish students mainly accept evolution, with several other countries showing less acceptance (see Fig. 4). However, the Turkish results should be interpreted with caution because of the small sample size $(n=85)$. Still, our comparison of 26 European countries reveals that country affiliation plays only a minimal role in explaining acceptance or rejection of evolution.

Within our extensive European sample of first-year university students, a very small share of students rejects or rather rejects evolution based on the interpretation categories (see Table 4). These students that reject evolution could be the focus of further analyses and studies. By focusing on this group, researchers could investigate the reasons for rejection in more detail and compare predictors for acceptance of evolution with the whole sample. In summary, only a minimal number of European firstyear university students reject evolution. 


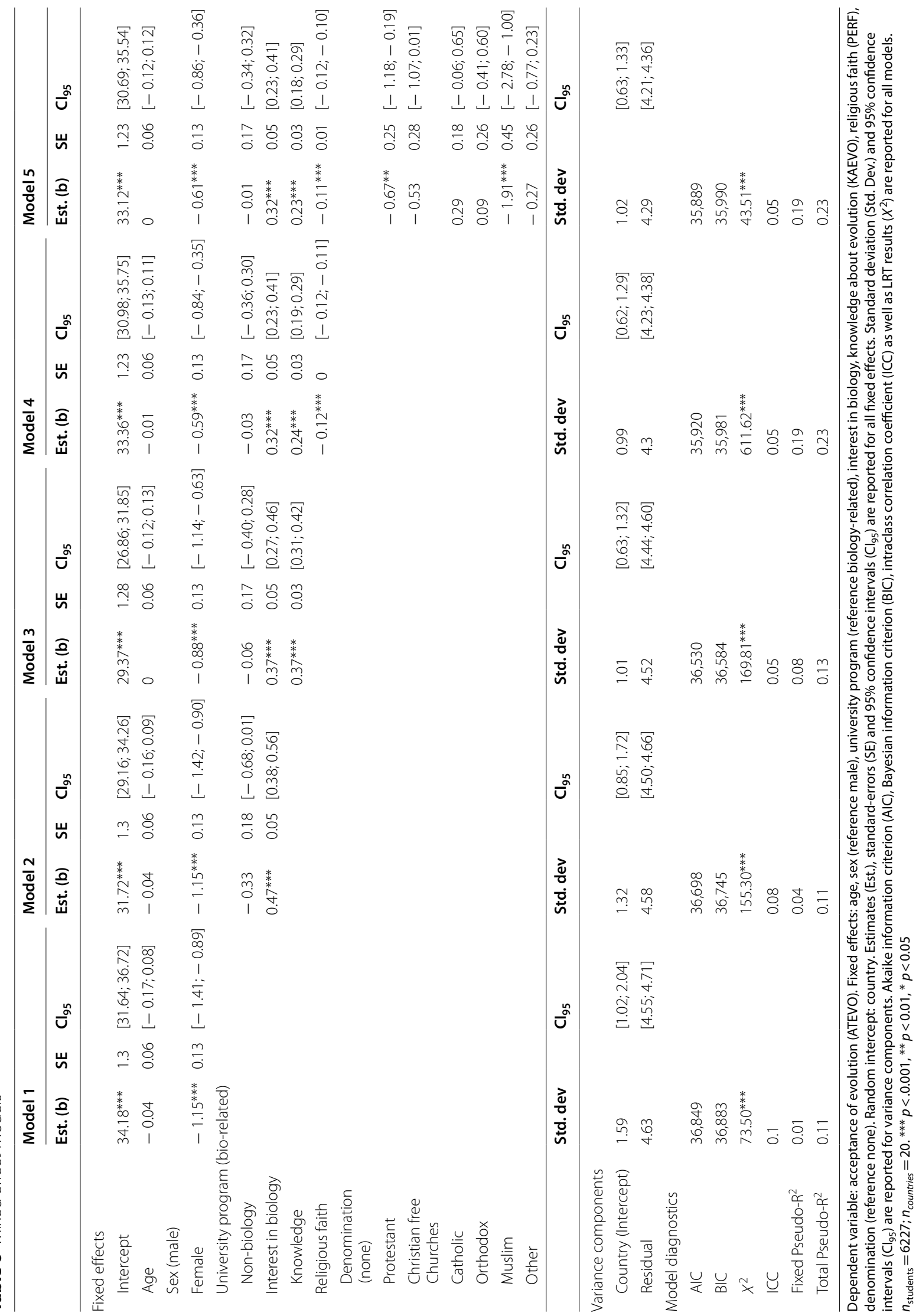




\section{European first-year university students, even those enrolled in biology-related programs, often lack knowledge about evolution}

The extent of knowledge about evolution is much more varied than in the case of acceptance in the investigated sample. The vast variance in knowledge is especially remarkable because the participants are homogeneous in age and educational level since they all just finished secondary education in their respective countries. Even among the students enrolled in a biology-related university program, the level of knowledge varies greatly (see Fig. 2); however, all students were surveyed before they were taught evolution at university. Previous studies found that knowledge about evolution among European university students generally increases with biology education (Kuschmierz et al. 2020b). However, some studies show low levels of expertise even for biology-related university students in Europe (Kuschmierz et al. 2020a; Pinxten et al. 2020). This disparity in the literature is supported by our results, as biology-related students knew significantly more about evolution than non-biology students, albeit the level of knowledge among biology-related students was not as high as one might expect in most countries. Additionally, the country samples differed much more in evolution knowledge than in evolution acceptance. This was true even within the biology-related students, though none had received evolution education at university previously. This effect may be explained by the varying coverage of evolution in national secondary school curricula. Before entering upper secondary education, students of almost all of the 26 surveyed European countries had been taught about evolution to some extent (Additional file 2). However, students graduating from upper secondary schools in Cyprus, Portugal, and Turkey may not have ever been taught evolution. Furthermore, during upper secondary education, differences between European countries can be found in the curricula. In some European countries, including France, Germany, the Netherlands, and Slovenia, whether students are taught about evolution, and to what extent, depends on the path they choose in secondary education. In other countries, such as Finland and Serbia, evolution is part of all students' curriculum.

Almost all surveyed students from Finland, the Netherlands, and Spain were enrolled in a biology-related study program, which may explain the high knowledge scores. Whereas evolution is compulsory in grades seven to nine in Finland, it is an elective topic for students in Spain and the Netherlands. In Latvia (96.6\% biology-related students), where the students had the lowest scores in knowledge about evolution, the amount of evolution lessons is similarly dependent on students' choices. In the Czech Republic (100\% biology-related students), where the students also had low scores in knowledge about evolution, students entering university usually attended compulsory evolution classes in upper secondary education. In Slovakia (95.9\% biology-related students), evolution classes are also required in upper secondary education; however, evolution is not a central theme in biology education (for information on the school curricula, see Additional file 2). In our Slovakian sample, students also showed low scores in knowledge about evolution.

Hence, it appears that the differences in knowledge between countries reflect neither the number of evolution lessons in the respective school curricula nor the share of biology-related students, at least not for the national samples included in the analysis (national sample size $n \geq 150$ ).

However, we cannot exclude the possibility that knowledge differences are related to the structure of national school curricula since we did not investigate the number of evolution lessons the students had and how evolution was addressed during their school career. Further studies should focus more on the relationship between evolution lessons during secondary education and knowledge about evolution. Additionally, the integration of evolution in school curricula regarding the specific topics addressed and concrete learning goals should be investigated. This would help to better understand what students in different countries learn about evolution and how this impacts their knowledge about evolution. Moreover, knowledge acquisition in evolution is crucially dependent on biology teachers' content knowledge as well as pedagogical content knowledge (Kuschmierz et al. 2020a). Therefore, pre-service biology teachers' educational training should be studied as a factor in student knowledge about evolution in future research, as it differs substantially between European countries (Evagorou et al. 2015). Furthermore, there may be barriers to teach evolution in school similar to those identified for higher education (Tolman et al. 2021). These have to be taken into account as well as potential difficulties in diagnosing student's misconceptions (Fischer et al. 2021).

\section{Religious faith predicts acceptance of evolution much more than knowledge about evolution and students' denomination}

Our results revealed a positive but rather weak relationship between evolution knowledge and acceptance. Previous studies in single European countries varied from no connection between these two constructs (Akyol et al. 2010; Athanasiou et al. 2016; Graf and Soran 2010; Tekkaya et al. 2012; Torkar and Šorgo 2020), to a weak (Akyol et al. 2012; Athanasiou et al. 2012; Graf and Soran 2010; Großschedl et al. 2014; Nehm et al. 2013) or moderate 
(Buchan 2019; Deniz and Sahin 2016; Großschedl et al. 2018; Mantelas and Mavrikaki 2020; Stanisavljevic et al. 2013) positive relationship. Furthermore, we found a negative correlation with a moderate effect between the religious faith and acceptance of evolution, which was also identified in previous studies across Europe (Annaç and Bahçekapılı 2012; Athanasiou et al. 2012; Beniermann 2019; Betti et al. 2020; Deniz et al. 2011; Deniz and Sahin 2016; Graf and Soran 2010; Southcott and Downie 2012).

In our study, religious faith influences acceptance of evolution much more than any other factor tested, including knowledge about evolution. Although religious faith alone cannot sufficiently explain the rejection of evolution (Beniermann 2019; McCain and Kampourakis 2018), it plays a vital role as a predictor within the group of students that identify as somewhat religious. It was shown that religious faith predicts the level of evolution acceptance for religious people regardless of other factors that have been shown to influence evolution acceptance for other samples (Allmon 2011; Rissler et al. 2014). The interaction of science and religion is a very sensitive issue, and instructors are often reluctant to discuss this topic with their students (Barnes and Brownell 2016; Southerland and Scharmann 2013). However, especially in rather religious regions, evolution education highly benefits from a cultural sensitivity and awareness of instructors (Barnes and Brownell 2017). One way to accomplish this is the use of the Religious Cultural Competence in Evolution Education framework (Barnes and Brownell 2017) that in particular addresses the competence to bridge cultural differences and enable effective communication with students with other cultural backgrounds than the instructor's. This approach might increase acceptance of evolution by reducing the perceived conflict between religion and evolution (Barnes and Brownell 2017), as this perceived conflict was demonstrated to impact evolution acceptance (Barnes et al. 2021b; Sbeglia and Nehm 2020). Moreover, addressing the compatibility between evolution and religion (Barnes et al. 2017a; Southerland and Scharmann 2013; Yasri and Mancy 2016), for instance, by referring to religious authorities and role models when teaching evolution (Holt et al. 2018; Mead et al. 2017), could reduce the students' conflict between these two topics. Thus, to foster evolution acceptance during teaching and increase the level of knowledge about evolution, teachers should be enabled to discuss the relationship between evolution and religion with their students and avoid the assumption that people, who accept evolution, are necessarily atheistic because it is associated with lower evolution acceptance for religious persons (Barnes et al. 2020). This might support learners to develop the competence to make sound judgments about the compatibility of evolution and religion (Mead et al. 2018).
It was previously shown that acceptance of evolution differs between denominations for university students in Austria, Germany, and the UK. Students without a denomination showed the highest scores (Beniermann 2019; Konnemann et al. 2016; Lammert 2012), while Christian Free Churchers (Beniermann 2019; Konnemann et al. 2016) and Muslims (Eder et al. 2011; Fenner 2013; Lammert 2012; Southcott and Downie 2012) showed the lowest scores. In agreement with those findings, in our study, Muslims accepted evolution significantly less than students without a denomination. In contrast to previous studies, however, Christian Free Churchers did not accept evolution significantly less than non-affiliated students, while Protestants showed significantly lower acceptance towards evolution. The different meanings of Free Churches as organizational structures across Europe (Elwert and Radermacher 2017) could explain this or because fundamental Evangelical religious practices are represented within Protestant communities in many European countries (Elwert and Radermacher 2017). However, the model fit decreased when adding denominations, indicating that denomination per se is not a significant predictor for accepting evolution, at least not in our sample. This finding agrees with previous studies, which revealed that the observed differences in acceptance of evolution between countries are mostly due to national socio-cultural background rather than denomination (Clément et al. 2012; Clément 2015).

In this sample, students' acceptance of evolution increased with their interest in biological topics. Although it is known that interest can foster the motivation to learn a topic (Harackiewicz et al. 2016; Hidi and Harackiewicz 2000), there is very little research on the interest in evolution (Barnes et al. 2021a; Ha et al. 2012a). In a previously conducted study, Korean and US biology majors and non-majors college students were assessed on acceptance of evolution, knowledge about evolution, interest in evolution, and religiosity ( $\mathrm{Ha}$ et al. 2012a). Korean college students showed higher knowledge about evolution and acceptance of evolution but lower religiosity and interest in evolution as US college students. This finding seems to contradict our finding that interest in evolution increases with accepting evolution. However, the role of interest for accepting evolution should be the focus of future studies.

Within the investigated sample, female students accept evolution less than male students. This is consistent with previous findings that showed the differences in acceptance of evolution are most likely related to the different degrees of religious faith between women and men (Beniermann 2019). However, in a recent study on Greek biology university students, differences in evolution 
acceptance between genders were observed even after controlling for religiosity (Mantelas and Mavrikaki 2020). Although the gender gap in religious faith is well known and consistent across Western countries and especially Christian cultures (Pew Research Center 2016; Sammet 2017), the existence of a gender gap in evolution acceptance and possible rationales could also be the focus of future studies.

\section{Limitations}

We acknowledge limits to our data's generalizability due to the differences in sample sizes and shares of biologyrelated and non-biology students within the surveyed countries. Even though our samples are not representative of single countries, our findings still offer added value. The large total sample size and the standardized comparison basis provide essential insights into European first-year university students' acceptance and knowledge about evolution. In contrast to other comparative surveys (Brenan 2019; Ipsos Global @dvisory 2011; Miller et al. 2006; Pew Research Center 2015), we gathered data with the same validated instrument, including various multiple-choice questions.

The research instrument was translated into 23 languages to be able to survey the respondents in their native language and the translation process is a source of potential bias, which we addressed by retranslating the questionnaire with the help of national experts in the field of biology or biology education. For translations in the future, we recommend using the Translation-ReviewAdjudication-Pre-test-Documentation (TRAPD; European Social Survey 2014) method. This method enables the reliable identification of problematic translations (Harkness 2003).

Each subsequent model in our multilevel model analysis explained more variance in acceptance of evolution than the previous model. This suggests that more predictors could have been added to the model, such as socio-cultural factors and the 'nature of science understanding' (Akyol et al. 2010; Graf and Soran 2010; Nelson et al. 2019), 'trust in science' (Graf and Soran 2010; Großschedl et al. 2014), perceived personal conflict with evolution (Sbeglia and Nehm 2020) or statistical thinking (Fiedler et al. 2019) that have been shown to interact with acceptance of evolution.

In terms of knowledge about evolution, we are limited to the evolutionary concepts covered in the study's questionnaire: evolutionary adaptation and natural selection, biological fitness, speciation, including variation, the heredity of phenotype changes, human evolution, and tree reading. When relating knowledge about evolution to the school curricula of the respective countries, it should be noted that the educational outcomes defined in the school curricula do not necessarily reflect actual knowledge about evolution gained by average students and must be interpreted with caution. Additionally, many other factors influence educational outcomes, such as teachers' experience and knowledge of general biology, and, in particular, evolutionary biology.

\section{Conclusions}

Our results showed that country affiliation only plays a minimal role in acceptance of evolution among European first-year university students, despite the varying cultural backgrounds and education systems. It would be interesting to extend these analyses beyond a clearly defined target group to a broader sample group to determine if our results can be confirmed on a greater scale. Additionally, further investigations should focus on the limited knowledge about evolution among students in Europe and potential gaps in school curricula regarding specific evolutionary topics. Our results suggest that merely increasing the number of evolution lessons may not be effective as this is not crucial for improving students' knowledge about evolution. A more detailed and standardized comparative analysis of the European school curricula could reveal potential differences, for instance, in terms of evolutionary concepts covered and specific learning goals. By analyzing our results in the context of the respective national school curricula concerning evolution (Additional file 2), we investigate potential correlations between national school curricula and evolution knowledge and acceptance. With the recently published "FACE" (Framework to Assess the Coverage of biological Evolution by school curricula; Sá-Pinto et al. 2021b), a tool for analyzing curricula, European school curricula could be analyzed and subsequently collated with our results. Furthermore, an in-depth investigation of results concerning knowledge about particular evolutionary concepts (e.g., evolutionary adaptation and tree reading) could reveal concept-dependent difficulties in understanding that should be covered explicitly in class. Moreover, in-class activities (e.g., Sá-Pinto et al. 2021a) could also be helpful to foster the understanding of evolution.

Our finding that religious faith predicts acceptance of evolution much more than knowledge about evolution implies that, besides increasing knowledge about evolution, emphasis should be placed on the relationship between evolution and religion when fostering evolution acceptance, for instance through approaches with emphasis on reasoning and argumentation (Beniermann et al. 2021a). However, instructors are often reluctant to address this sensitive topic; thus, teaching validated modules of high didactic quality and acknowledging challenges in understanding as well as fostering cultural competence (Barnes and Brownell 2017) could reduce 
teachers' uncertainty when addressing this issue with their students.

\begin{abstract}
Abbreviations
a: Cronbach's alpha; AIC: Akaike information criterion; ATEVO: Attitudes towards evolution; BIC: Bayesian information criterion; $\mathrm{Cl}_{95}$ : 95\% Confidence interval; EEQ: Evolution Education Questionnaire; Est.: Estimates; FACE: Framework to Assess the Coverage of biological Evolution by school curricula; ICC: Intraclass correlation coefficient; IQR: Interquartile range; KAEVO: Knowledge about evolution; KAEVO-A: Part A of the knowledge about evolution questionnaire; M: Mean; $N$ : Total sample size; $n$ : Sample size; PAF: Principal axis factoring; PERF: Personal religious faith; Q1: Quartile 1; Q3: Quartile 3; QQ-plots: Quantile-quantile-plots; r: Pearson correlation; SD: Standard deviation; SE: Standard-error; TRAPD: Translation-Review-Adjudication-Pre-test-Documentation; $\chi^{2}$ : LRT results.
\end{abstract}

\section{Supplementary Information}

The online version contains supplementary material available at https://doi. org/10.1186/s12052-021-00158-8.

Additional file 1. List of university programs that occur in our study and are considered as biology related.

Additional file 2. Overviews of European national school curricula concerning the subject Biology and the topic "evolution".

Additional file 3. Original data set.

Additional file 4. R-script.

Additional file 5. R-scriptdonedone.

Additional file 6. Country-specific EFA.

\section{Acknowledgements}

Silvia Paolucci, a dear friend and one of the authors of the present research, recently passed away. We all gratefully dedicate this paper to her memory. This article is based upon work from COST Action 17127 (EuroScitizen: Building on scientific literacy in evolution towards scientifically responsible Europeans), supported by COST (European Cooperation in Science and Technology; www.cost.eu). We acknowledge this support for offering a research network in which such research projects can be realized.

We thank the following researchers for surveying their student classes: D. Aksamit, G. Anačkov, S. Balan, J. M. Bautista, S. Beltran-Bech, P. Catalán, B. Dinić, A. Engl, J. Enroth, P. Ferreira, D. Franjević, M. Georgiou, F. Ghiselli, F. Giraldez, F. Grigenti, H.-M. Haase, J. Haimi, U. Hoßfeld, M. C. Invernizzi, N. Kević, M. Kiehn, D. Kirsch-Tietz, C. Koch, M. A. Koperska, P. Kordos, E. Kuusela, L. Kvist, M. Lazarević, K. Lindström, R. Mangano, B. Mantovani, D. Miljković, E. Morri, M. Müller, F. Nazzi, P. Onkamo, J. M. Ortega, T. Pandolfini, M. Popov, G. Preisfeld, J. G. Puerta, J. Puizina, A. Raabe, M. B. Rasotto, E. Rolan, J. M. B. Santa Cruz, R. Santolini, M. Á. Serrano, J. Šic Žlabur, E. L. Simón, N. Sinčić, L. Sundström, E. Viguera, Ö. Yahyaoglu, and N. Zlatić.

We thank the following researchers for giving us the chance to survey their students: T. Bartsch, A. Bensa, K. Damnjanović, J. Foegele, T. Ivanković, B. Jauker, T. Kahler, R. Köhl, T. Möbius, J. Roth-Brennecke, E. Schmidt, M. Spies, C. Staszyk, and A. Wysocka.

We thank R. Martincová for helping with the overview of the Slovakian school curricula.

We thank G. Endresz, Z. Krakomperger, K. Molnár, and G. Nádori for helping with the overview of the Hungarian school curricula.

We thank M. Billek, K. Hrvatinić, M. Pešut, D. Poljuha, H. Semmler, and B. Žujović for technical support and help with data digitization.

\section{Authors' contributions}

PK was the principal investigator of this project. ABen, DG, and PK designed and planned the study. ABen and DG supervised this project. $A B e n$ and RP lead the working group. ABen, ÁB-R, AMo, AŠ, ANS, AU, AV, ÁZL, BC, BP, CF, KK, DC, DG, GB, GR, GT, JB-W, JF, JP, JZ, LT, LV-B, MF, MP, MS, MTS, NGea, NGer, PC, $P K, P L P, R M D, R P, S D, S P, T A, U B C, X S-P$, and $Z N$ were involved in the translation process of the questionnaire. ABen, $A L, A M e, A M O ̈, A N S, A P, A S ̌, A U, A V, B C$, $B P, C F, K K, D C, D G, G R, G T, I Y, J B-W, J F, J P, J Z, M \bigoplus, M F, M P, M S, M T S, M i V$, NGea, NGer, PK, RMD, RP, SP, ST, TA, TP, US, XS-P, and ZN organized conductions of the survey with multiple departments or universities involved. AMo, AMö, DAG, ED, EM, EV, IT, KO-P, LV-B, MáV, PC, PGM, PLP, UBC, and YN provided one sample each. PK and RP (only data for Belgium) digitalized the data. ABen, ABer, and PK analyzed the data. ABer created Figs. 2, 3, and 4 for the paper. PK wrote the draft of the paper. ABen, ABer, ÁB-R, AMe, AMo, AMö, ANS, APobric, AŠorgo, $A U, A V, A Z L, B C, B P, C F, K K, D A G, D C, D G, E D, E M, E V, G B, G R$, GT, IT, IY, JB-W, JF, JP, JZ, KO-P, LD, LT, LV, LV-B, MĐ, MF, MP, MS, MTS, MáV, MiV, NGea, NGer, PC, PGM, PLP, RMD, RP, SD, SP, ST, TA, TP, UBC, US, XS-P, YN, and ZN proofread the draft. ABen, ÁB-R, AMe, AMö, ANS, AŠorgo, AU, AV, ÁZL, CF, KK, DAG, DC, ED, EM, EV, GR, GT, IT, JF, JP, JZ, KO-P, LT, LD, LV, LV-B, MĐ, MF, MS, MTS, MáV, NGer, PGM., PK, RMD, RP, SD, SP, ST, TA, TP, UBC, US, XS-P, and YN were involved in writing the overview of the school curricula. All authors read and approved the final manuscript.

\section{Funding}

Open Access funding enabled and organized by Projekt DEAL and COST (European Cooperation in Science and Technology; http://www.cost.eu). Networking activities for the purpose of this project, as well as a professional proofread, were funded by COST via COST Action 17127.

\section{Availability of data and materials}

The authors declare that the data supporting the findings of this study are available within the paper and its Additional files. Raw data as well as all relevant code for data analysis are included in the Additional files.

\section{Declarations}

\section{Ethics approval and consent to participate}

The participation was voluntary and anonymous. All participants have been informed about the study's objectives and the use of the data. No harm resulted from non-participation. Since students participated voluntarily, chose to participate or not prior to the survey, we assumed implicit informed consent.

Ethical guidelines as prescribed by the European Commission (2018), the German Research Foundation (2020) and the Office for Human Research Protections (2020) have been followed during planning and conducting the study.

\section{Consent for publication}

Not applicable.

\section{Competing interests}

The author(s) declare(s) that they have no competing interests.

\section{Author details}

${ }^{1}$ Institute for Didactics of Biology, Justus-Liebig-University Giessen, Giessen, Germany. ${ }^{2}$ Institute for Biology; Teaching and Learning Research in Biology Education, Humboldt-Universität Zu Berlin, Berlin, Germany. ${ }^{3}$ Faculty of Life Science, Department of Biology, University of Leipzig, Leipzig, Germany. ${ }^{4}$ Didactica Research Unit, Faculty of Social Sciences \& Behavioural Ecology \& Ecophysiology Group, Department of Biology, University of Antwerp, Antwerp, Belgium. ${ }^{5}$ Organismal and Evolutionary Biology Research Program, University of Helsinki, Helsinki, Finland. ${ }^{6}$ University of Information Technology and Management in Rzeszów, Rzeszów, Poland. ${ }^{7}$ Public \& Science (VA), Stockholm, Sweden. ${ }^{8}$ Department of Pedagogy and Didactics, University of A Coruña, A Coruña, Spain. ${ }^{9}$ Escola Superior de Educação, Politécnico do Porto, Porto, Portugal. ${ }^{10}$ Department of Science and Mathematics, Polytechnic Institute of Santarém/School of Education, Santarém, Portugal. ${ }^{11}$ Faculty of Education/ Department of Mathematics and Science Education, Usak University, Uşak, Turkey. ${ }^{12}$ Chair of Genetics and Evolution, Faculty of Biology, University of Belgrade, Belgrade, Serbia. ${ }^{13}$ Department of Botany and Plant Biology, University of Geneva, Geneva, Switzerland. ${ }^{14}$ Department of Evolutionary Biology, Institute for Biological Research "Siniša Stanković" - National Institute of Republic of Serbia, University of Belgrade, Belgrade, Serbia. ${ }^{15}$ Institute of Environmental Sciences, Jagiellonian University, Kraków, Poland. ${ }^{16}$ Department of Parliamentarism and Political Management, National Academy for Public Administration Under the President of Ukraine, Kyiv, Ukraine. ${ }^{17}$ Department of Teaching and Didactics of Biology, Charles University, Praha, Czech Republic. 
${ }^{18}$ Department of Biology, Faculty of Education, Trnava University, Trnava, Slovakia. ${ }^{19}$ Laboratory of Didactic André Revuz, University of Paris, Paris, France. ${ }^{20}$ Institut Ruđer Bošković/Division of Molecular Biology, Zagreb, Croatia. ${ }^{21}$ Department/Research Center in Systems Ecology and Sustainability, University of Bucharest, Bucharest, Romania. ${ }^{22}$ Department of Environmental and Life Sciences, Karlstad University, Karlstad, Sweden. ${ }^{23}$ Department of Chemistry, Life Sciences and Environmental Sustainability, University of Parma, Parma, Italy. ${ }^{24}$ Department of Evolutionary Zoology and Human Biology, University of Debrecen, Debrecen, Hungary. ${ }^{25}$ Primary Education Department, National and Kapodistrian University of Athens, Athens, Greece. ${ }^{26}$ Department of Biology (DiBio), University of Padua, Padua, Italy. ${ }^{27}$ Department of Primary Education, Democritus University of Thrace, Alexandroupolis, Greece. ${ }^{28}$ Austrian Educational Competence Centre of Biology, University of Vienna, Vienna, Austria. ${ }^{29} \mathrm{CIBIO}$, University of Porto, Porto, Portugal. ${ }^{30}$ Plant Systematics and Biodiversity Laboratory, Conservatoire et Jardin Botanique de Genève \& University of Geneva, Geneva, Switzerland. ${ }^{31}$ Humanities and Social Sciences, University of Bielsko-Biala, Bielsko-Biala, Poland. ${ }^{32}$ Laboratorio di Scienze Sperimentali, Foligno, Italy. ${ }^{33}$ Evolutionary Ecology Group, Hungarian Department of Biology and Ecology, Babeş-Bolyai University, Cluj Napoca, Romania. ${ }^{34}$ Department of Educational Studies, Karlstad University, Karlstad, Sweden. ${ }^{35}$ Faculty of Biology/Institute of Functional Biology and Ecology/Department of Hydrobiology, University of Warsaw, Warsaw, Poland. ${ }^{36}$ Faculty of Science, University of Sarajevo, Sarajevo, Bosnia and Herzegovina. ${ }^{37}$ Faculty of Education, Psychology and Art, University of Latvia, Riga, Latvia. ${ }^{38}$ Geology Section - UNICAMearth Group, University of Camerino, Camerino, Italy. ${ }^{39}$ Research Centre in Didactics and Technology in Teacher Training, Department of Education and Psychology, University of Aveiro, Aveiro, Portugal. ${ }^{40}$ Institut des Sciences de l'évolution (UM, IRD, CNRS), Université de Montpellier, Montpellier France. ${ }^{41}$ MIVEGEC, Université de Montpellier, Montpellier, France. ${ }^{42}$ Faculty of Natural Sciences and Mathematics, University of Maribor, Maribor, Slovenia. ${ }^{43}$ Department of Taxonomy and Ecology, Babes-Bolyai University, Cluj-Napoca, Romania. ${ }^{44}$ Applied Ecology Research Centre, Lucian Blaga University of Sibiu, Sibiu, Romania. ${ }^{45}$ Faculty of Education, University of Ljubljana, Ljubljana, Slovenia. ${ }^{46}$ Faculty of Philosophy, University of Banja Luka, Banja Luka, Bosnia and Herzegovina. ${ }^{47}$ Department of Education, Faculty of Educational Sciences, University of Helsinki, Helsinki, Finland. ${ }^{48}$ Department of Genetics, ELTE Eötvös Loránd University, Budapest, Hungary. ${ }^{49}$ Faculty of Humanities and Social Sciences Osijek, University of Osijek, Osijek, Croatia. ${ }^{50}$ Department of Education, University of Cyprus, 1678 Nicosia, Cyprus. ${ }^{51}$ Facultad de Ciencias/Departamento de Biologia Celular, Genetica y Fisiologia, Universidad de Malaga, Malaga, Spain. ${ }^{52}$ School of Education, Universität Salzburg, Salzburg, Austria. ${ }^{53}$ Faculty of Economic and Business Adminstration - FEBA, Sofia University "St. Kliment Ohridski", Sofia, Bulgaria. ${ }^{54}$ Estación Experimental de Aula Dei, Spanish National Research Council (CSIC), Zaragoza, Spain. ${ }^{55}$ Institute of Education Biology , Utrecht University, Utrecht, The Netherlands.

Received: 7 September 2021 Accepted: 20 November 2021 Published: 30 November 2021

\section{References}

Aiken LS, West SG, Reno RR. Multiple regression: testing and interpreting interactions. London: Sage; 1991.

Akyol G, Tekkaya C, Sungur S. The contribution of understandings of evolutionary theory and nature of science to pre-service science teachers' acceptance of evolutionary theory. Proc Soc Behav. 2010;9:1889-93. https://doi.org/10.1016/j.sbspro.2010.12.419.

Akyol G, Tekkaya C, Sungur S, Traynor A. Modeling the interrelationships among pre-service science teachers' understanding and acceptance of evolution, their views on nature of science and self-efficacy beliefs regarding teaching evolution. J Sci Teach Educ. 2012;23(8):937-57. https://doi.org/10.1007/s10972-012-9296-x.

Allmon WD. Why don't people think evolution is true? Implications for teaching, in and out of the classroom. Evol Educ Outreach. 2011;4(4):648-65. https://doi.org/10.1007/s12052-011-0371-0.

American Educational Research Association, American Psychological Association, National Council on Measurement in Education. Standards for educational and psychological testing. Washington, DC: American Educational Research Association; 1999.
Annaç E, Bahçekapılı HG. Understanding and acceptance of evolutionary theory among Turkish university students. Doğuş Üniversitesi Dergisi. 2012:13:1-11.

Arthur S. Evolution acceptance among pre-service primary teachers. Evol Educ Outreach. 2013;6(1):1-1. https://doi.org/10.1186/1936-6434-6-20.

Athanasiou K, Papadopoulou P. Conceptual ecology of the evolution acceptance among Greek education students: knowledge, religious practices and social influences. Int J Sci Educ. 2012;34(6):903-24. https://doi.org/ 10.1080/09500693.2011.586072.

Athanasiou K, Katakos E, Papadopoulou P. Conceptual ecology of evolution acceptance among Greek education students: the contribution of knowledge increase. J Biol Educ. 2012;46(4):234-41. https://doi.org/10. 1080/00219266.2012.716780.

Athanasiou K, Katakos E, Papadopoulou P. Acceptance of evolution as one of the factors structuring the conceptual ecology of the evolution theory of Greek secondary school teachers. Evol Educ Outreach. 2016;9(1):1-5. https://doi.org/10.1186/s12052-016-0058-7.

Barnes ME, Brownell SE. Practices and perspectives of college instructors on addressing religious beliefs when teaching evolution. CBE Life Sci Educ. 2016;15(2):1-19. https://doi.org/10.1187/cbe.15-11-0243.

Barnes ME, Brownell SE. A call to use cultural competence when teaching evolution to religious college students: introducing religious cultural competence in evolution education (ReCCEE). CBE Life Sci Educ. 2017;16(4):es4.

Barnes ME, Elser J, Brownell SE. Two-week evolution module reduces perceived conflict between evolution and religion for religious and non-religious students. Am Biol Teach. 2017a;79(2):104-11. https://doi. org/10.1525/abt.2017.79.2.104.

Barnes ME, Evans EM, Hazel A, Brownell SE, Nesse RM. Teleological reasoning, not acceptance of evolution, impacts students' ability to learn natural selection. Evol Educ Outreach. 2017b;10(1):1-2.

Barnes ME, Dunlop HM, Holt EA, Zheng Y, Brownell SE. Different evolution acceptance instruments lead to different research findings. Evol Educ Outreach. 2019;12(1):1-7. https://doi.org/10.1186/s12052-019-0096-z.

Barnes ME, Dunlop HM, Sinatra GM, Hendrix TM, Zheng Y, Brownell SE. "Accepting Evolution Means You Can't Believe in God": atheistic perceptions of evolution among college biology students. CBE Life Sci Educ. 2020;19(2):ar21. https://doi.org/10.1187/cbe.19-05-0106.

Barnes ME, Roberts JA, Maas SA, Brownell SE. Muslim undergraduate biology students' evolution acceptance in the United States. PLoS ONE. 2021a;16(8):e0255588.

Barnes ME, Supriya K, Zheng Y, Roberts JA, Brownell SE. A new measure of students' perceived conflict between evolution and religion (PCORE) is a stronger predictor of evolution acceptance than understanding or religiosity. CBE Life Sci Educ. 2021b;20(3):ar42.

Bates D, Mächler M, Bolker B, Walker S. Fitting linear mixed-effects models using Ime4. J Stat Softw. 2015;67:1-48. https://doi.org/10.18637/jss. v067.i01.

Beniermann A. Evolution-Von Akzeptanz und Zweifeln, Empirische Studienüber Einstellungen zu Evolution und Bewusstsein [Evolution - ofacceptance and doubts, Empirical studies on attitudes towards evolutionand the evolution of the human mind]. Wiesbaden: Springer Fachmedien; 2019.

Beniermann A, Mecklenburg L, Upmeier zu Belzen A. Reasoning on controversial science issues in science education and science communication. Educ Sci. 2021 a;11(9):522.

Beniermann A, Kuschmierz P, Pinxten R, Aivelo T, Bohlin G, Brennecke JS, et al. Evolution Education Questionnaire on Acceptance and Knowledge (EEQ)-Standardised and ready-to-use protocols to measure acceptance of evolution and knowledge about evolution in an international context. 2021 b. Zenodo. https://doi.org/10.5281/zenodo.4554742.

Betti L, Shaw P, Behrends V. Acceptance of biological evolution by first-year life sciences University Students. Sci Educ. 2020;29:395-409. https://doi. org/10.1007/s11191-020-00110-0.

Bilen K, Ercan O. Tendencies of comprehension and acceptance of theory of evolution: a study involving students from the faculties of education and theology. Int J Environ Sci Educ. 2016;11(9):3101-15.

Bishop BA, Anderson CW. Student conceptions of natural selection and its role in evolution. J Res Sci Teach. 1990;27(5):415-27. https://doi.org/10. 1002/tea.3660270503. 
Brenan M. 40\% of Americans believe in creationism. Gallup. 2019. https:// news.gallup.com/poll/261680/americans-believe-creationism.aspx. Accessed 4 Sept 2021.

Buchan L. Development and evaluation of resources for teaching evolution in primary schools. Doctoral dissertation, University of Bath. 2019.

Clément P. Creationism, science and religion: a survey of teachers' conceptions in 30 countries. Procedia Soc Behav Sci. 2015;167:279-87. https://doi. org/10.1016/j.sbspro.2014.12.675.

Clément P, Quessada MP, Castéra J. Creationism and innatism of teachers in 26 countries. In: IOSTE XVth international symposium science \& technology education for development, citizenship, and social justice Tunisia. 2012.

Deniz H, Borgerding LA. Evolution education around the globe. Berlin: Springer; 2018.

Deniz $\mathrm{H}$, Sahin EA. Exploring the factors related to acceptance of evolutionary theory among Turkish Preservice Biology Teachers and the relationship between acceptance and teaching preference. Electron J Sci Educ. 2016;20(4):21-43

Deniz $\mathrm{H}$, Çetin F, Yılmaz I. Examining the relationships among acceptance of evolution, religiosity, and teaching preference for evolution in Turkish preservice biology teachers. Reports of the National Center for Science Education. 2011;31(4)

Dobzhansky T. Nothing in biology makes sense except in the light of evolution. Am Biol Teach. 1973;35:125-9.

Dunk RD, Petto AJ, Wiles JR, Campbell BC. A multifactorial analysis of acceptance of evolution. Evol Educ Outreach. 2017;10:4. https://doi.org/10. 1186/s12052-017-0068-0.

Dunk RD, Barnes ME, Reiss MJ, Alters B, Asghar A, Carter BE, et al. Evolution education is a complex landscape. Nat Ecol Evol. 2019;3(3):327-9.

Eagly AH, Chaiken S. The psychology of attitudes. San Diego: Harcourt Brace Jovanovich College Publishers; 1993.

Eder E, Turic K, Milasowszky N, Van Adzin K, Hergovich A. The relationships between paranormal belief, creationism, intelligent design and evolution at secondary schools in Vienna (Austria). Sci Educ. 2011;20(5):51734. https://doi.org/10.1007/s11191-010-9327-y.

Elsdon-Baker F. Creating creationists: The influence of 'issues framing'on our understanding of public perceptions of clash narratives between evolutionary science and belief. Pub Underst Sci. 2015;24(4):422-39.

Elwert F, Radermacher M. Evangelikalismus in Europa [Evangelicalism in Europe]. In: Schlamelcher J, editor. Handbuch Evangelikalismus. Bielefeld: transcript Verlag; 2017. p. 173-88. https://doi.org/10.15496/publi kation-40168.

Eurobarometer S. Europeans, science and technology. European Commission. 2005.

European Commission. Ethics in social science and humanities. 2018. https:// ec.europa.eu/info/sites/info/files/6._h2020_ethics-soc-science-human ities_en.pdf. Accessed 4 Sept 2021.

European Social Survey. ESS Round 7 translation guidelines. London: ESS ERIC Headquarters, Centre for Comparative Social Surveys, City University London; 2014.

Evagorou M, Dillon J, Viiri J, Albe V. Pre-service science teacher preparation in Europe: comparing pre-service teacher preparation programs in England, France, Finland and Cyprus. J Sci Teach Educ. 2015;26(1):99-115. https://doi.org/10.1007/s10972-015-9421-8.

Fenner A. Schülervorstellungen zur Evolutionstheorie: Konzeption und Evaluation von Unterricht zur Anpassung durch Selektion [School students' conceptions about the theory of evolution: development and evaluation of classes about adaptation by selection]. Doctoral dissertation, Justus-Liebig-University Giessen. 2013.

Fiedler D, Sbeglia GC, Nehm RH, Harms U. How strongly does statistical reasoning influence knowledge and acceptance of evolution? J Res Sci Teach. 2019;56(9):1183-206.

Field A. Discovering statistics using SPSS: (and sex and drugs and rock'n'roll). London: Sage; 2009

Fischer J, Jansen T, Möller J, Harms U. Measuring biology trainee teachers' professional knowledge about evolution -introducing the Student Inventory. Evol Educ Outreach. 2021;14(1):1-6.

Gefaell J, Prieto T, Abdelaziz M, Álvarez I, Antón J, Arroyo J, Bella JL, Botella M, Bugallo A, Claramonte V, Gijón J. Acceptance and knowledge of evolutionary theory among third-year university students in Spain. PLoS ONE. 2020;15(9):e0238345. https://doi.org/10.1371/journal.pone.0238345.
German Research Foundation. Ethics approval in social sciences. 2020. https:// www.dfg.de/foerderung/faq/geistes_sozialwissenschaften. Accessed 4 Sept 2021.

Glaze AL, Goldston MJ. US science teaching and learning of evolution: a critical review of the literature 2000-2014. Sci Educ. 2015;99(3):500-18.

Göransson A, Orraryd D, Fiedler D, Tibell LA. Conceptual characterization of threshold concepts in student explanations of evolution by natural selection and effects of item context. CBE Life Sci Educ. 2020;19(1):ar1. https://doi.org/10.1187/cbe.19-03-0056.

Graf D, Soran H. Einstellung und Wissen von Lehramtsstudierenden zur Evolution-ein Vergleich zwischen Deutschland und der Türkei. [Pre-service teachers' attitudes and knowledge about evolution-a comparison between Germany and Turkey]. In: Graf D, editor. Evolutionstheorie -Akzeptanz und Vermittlung im europäischen Vergleich. Heidelberg: Springer; 2010. p. 141-61.

Großschedl J, Konnemann C, Basel N. Pre-service biology teachers'acceptance of evolutionary theory and their preference for its teaching. Evol Educ Outreach. 2014;7(1):1-6. https://doi.org/10.1186/s12052-014-0018-z.

Großschedl J, Seredszus F, Harms U. Angehende Biologielehrkräfte: evolutionsbezogenes Wissen und Akzeptanz der Evolutionstheorie. [Future biology teachers: evolutionary knowledge and acceptance of the evolutionary theory]. Zeitschrift Für Didaktik Der Naturwissenschaften. 2018;24(1):51-70. https://doi.org/10.1007/s40573-018-0072-0.

Grunspan DZ, Dunk RD, Barnes ME, Wiles JR, Brownell SE. A comparison study of human examples vs. non-human examples in an evolution lesson leads to differential impacts on student learning experiences in an introductory biology course. Evol Educ Outreach. 2021;14(1):1-4.

$\mathrm{Ha} \mathrm{M}, \mathrm{Cha} \mathrm{H}, \mathrm{Ku}$ S. A comparative study of Korean and United States college students' degree of religiosity, evolutionary interest, understanding and acceptance and their structures. J Korean Elem Sci Educ. 2012a;32(10):1537-50.

Ha M, Haury DL, Nehm RH. Feeling of certainty: uncovering a missing link between knowledge and acceptance of evolution. J Res Sci Teach. 2012b;49(1):95-121. https://doi.org/10.1002/tea.20449.

Ha M, Baldwin BC, Nehm RH. The long-term impacts of short-term professional development: science teachers and evolution. Evol Educ Outreach. 2015:8(1):1-23.

Ha M, Wei X, Wang J, Hou D, Nehm RH. Chinese pre-service biology teachers' evolutionary knowledge, reasoning patterns, and acceptance levels. Int J Sci Educ. 2019:41(5):628-51.

Hameed S. Bracing for Islamic creationism. Science. 2008;322(5908):1637-8. https://doi.org/10.1126/science.1163672.

Harackiewicz JM, Smith JL, Priniski SJ. Interest matters: the importance of promoting interest in education. Policy Insights Behav Brain Sci. 2016;3(2):220-7.

Harkness J. Questionnaire translation. In: Harkness J, van de Vijver F, Mohler P, editors. Cross-cultural survey methods. Hoboken: Wiley; 2003. p. 35-56.

Harms U, Reiss MJ. Evolution education re-considered. Understanding what works. Cham: Springer; 2019.

Hidi S, Harackiewicz JM. Motivating the academically unmotivated: a critical issue for the 21st century. Rev Educ Res. 2000;70(2):151-79.

Holt EA, Ogden TH, Durham SL. The positive effect of role models in evolution instruction. Evol Educ Outreach. 2018;11(1):1-3. https://doi.org/10. 1186/s12052-018-0086-6.

Ingram EL, Nelson CE. Relationship between achievement and students' acceptance of evolution or creation in an upper-level evolution course. J Res Sci Teach. 2006;43(1):7-24.

Ipsos Global @dvisory. Supreme being(s), the afterlife and evolution. 2011.

Irez S, Bakanay ÇD. An assessment into pre-service biology teachers' approaches to the theory of evolution and nature of science. Eğitim Ve Bilim. 2011;36(162):39-55.

Johnson PC. Extension of Nakagawa \& Schielzeth's R_GLMM^2 to random slopes models. Methods Ecol Evol. 2014;5(9):944-6. https://doi.org/10. 1111/2041-210X.12225.

Kampourakis K, Strasser BJ. The evolutionist, the creationist, and the 'unsure': picking-up the wrong fight? Int J Sci Edu Part B. 2015;5(3):271-5.

Koller M. robustlmm: an R package for robust estimation of linear mixedeffects models. J Stat Softw. 2016;75(6):1-24. https://doi.org/10.18637/ jss.v075.i06

Konnemann C, Asshoff R, Hammann M. Einstellungen zur Evolutionstheorie: Theoretische und messtheoretische Klärungen [Attitudes towards 
evolutionary theory: theoretical and psychometric issues]. Zeitschrift Für Didaktik Der Naturwissenschaften. 2012;18:55-79.

Konnemann C, Asshoff R, Hammann M. Insights into the diversity of attitudes concerning evolution and creation: a multidimensional approach. Sci Educ. 2016;100(4):673-705. https://doi.org/10.1002/sce.21226.

Konnemann C, Höger C, Asshoff R, Hammann M, Rieß W. A role for epistemic insight in attitude and belief change? Lessons from a cross-curricular course on evolution and creation. Res Sci Educ. 2018;48(6):1187-204. https://doi.org/10.1007/s11165-018-9783-y.

Kralj L, Šalamon T, Lukša Ž. Usporedba znanja hrvatskih i slovenskih osnovnoškolaca te gimnazijalaca o evoluciji čovjeka. Educatio Biologiae: Časopis Edukacije Biologije. 2018. https://doi.org/10.32633/eb.4.2.

Kuschmierz P, Beniermann A, Graf D. Development and evaluation of the knowledge about evolution 2.0 instrument (KAEVO 2.0). Int I Sci Educ. 2020a;42(15):2601-29.

Kuschmierz P, Meneganzin A, Pinxten R, Pievani T, Cvetković D, Mavrikaki E, Graf D, Beniermann A. Towards common ground in measuring acceptance of evolution and knowledge about evolution across Europe: a systematic review of the state of research. Evol Educ Outreach. 2020b;13(1):1-24.

Lammert N. Akzeptanz, Vorstellungen und Wissen von Schülerinnen und Schülern der Sekundarstufe I zu Evolution und Wissenschaft. [Acceptance, conceptions, and knowledge of lower secondary education students about evolution and science]. Doctoral dissertation, TU Dortmund University. 2012.

Maas $\mathrm{CJ}$, Hox JJ. Sufficient sample sizes for multilevel modeling. Methodology. 2005; 1(3):86-92

Mantelas N, Mavrikaki E. Religiosity and students' acceptance of evolution. Int J Sci Educ. 2020;3:1-22.

McCain K, Kampourakis K. Which question do polls about evolution and belief really ask, and why does it matter? Public Underst Sci. 2018;27(1):2-10. https://doi.org/10.1177/0963662516642726.

McNeish DM, Stapleton LM. The effect of small sample size on two-level model estimates: a review and illustration. Educ Psychol Rev. 2016;28(2):295-314. https://doi.org/10.1007/s10648-014-9287-x.

Mead R, Hejmadi M, Hurst LD. Teaching genetics prior to teaching evolution improves evolution understanding but not acceptance. PLoS Biol. 2017;15(5):e2002255. https://doi.org/10.1371/journal.pbio.2002255.

Mead R, Hejmadi M, Hurst LD. Scientific aptitude better explains poor responses to teaching of evolution than psychological conflicts. Nat Ecol Evol. 2018;2(2):388-94. https://doi.org/10.1038/s41559-017-0442-x.

Mead LS, Kohn C, Warwick A, Schwartz K. Applying measurement standards to evolution education assessment instruments. Evol Educ Outreach. 2019;12(1):1-4. https://doi.org/10.1186/s12052-019-0097-y.

Miller JD, Scott EC, Okamoto S. Public acceptance of evolution. Science. 2006;313(5788):765. https://doi.org/10.1126/science.1126746.

Miller JD, Scott EC, Ackerman MS, Laspra B, Branch G, Polino C, Huffaker JS. Public acceptance of evolution in the United States, 1985-2020. Public Underst Sci. 2021. https://doi.org/10.1177/09636625211035919.

Nadelson LS, Sinatra GM. Educational professionals'knowledge and acceptance of evolution. Evol Psychol. 2009;7(4):490-516. https://doi.org/10. $1177 / 147470490900700401$

Nakagawa S, Schielzeth H. A general and simple method for obtaining R2 from generalized linear mixed-effects models. Methods Ecol Evol. 2013;4(2):133-42. https://doi.org/10.1111/j.2041-210x.2012.00261.x.

Nehm RH, Mead LS. Evolution assessment: introduction to the special issue. Evol Educ Outreach. 2019;12(7):1-5.

Nehm RH, Ha M, Großschedl J, Harms U, Roshayanti F. American, German, Korean, and Indonesian pre-service teachers' evolutionary acceptance, knowledge, and reasoning patterns. In: The proceedings of the National Association for Research in Science Teaching (NARST) conference, April 2013.

Nelson CE, Scharmann LC, Beard J, Flammer LI. The nature of science as a foundation for fostering a better understanding of evolution. Evol Educ Outreach. 2019;12:6. https://doi.org/10.1186/s12052-019-0100-7.

Novick LR, Catley KM. Assessing students' understanding of macroevolution: concerns regarding the validity of the MUM. Int J Sci Educ. 2012;34(17):2679-703. https://doi.org/10.1080/09500693.2012.727496.

Office for Human Research Protections, US Department of Health and Human Services. Criteria for human research regulations. 2020. https://www.
ecfr.gov/cgi-bin/text-idx?tpl=/ecfrbrowse/Title45/45cfr46_main_02.tpl. Accessed 4 Sept 2021.

Pew Research Center. Strong role of religion in views about evolution and perceptions of scientific consensus. 2015.

Pew Research Center. The Gender Gap in religion around the world. 2016.

Pinxten R, Vandervieren E, Janssenswillen P. Does integrating natural selection throughout upper secondary biology education result in a better understanding? A cross-national comparison between Flanders, Belgium and the Netherlands. Int J Sci Educ. 2020;42(10):1609-34. https:// doi.org/10.1080/09500693.2020.1773005.

Pobiner B. Accepting, understanding, teaching, and learning (human) evolution: obstacles and opportunities. Am J Phys Anthropol. 2016;159:23274. https://doi.org/10.1002/ajpa.22910.

Rissler LJ, Duncan SI, Caruso NM. The relative importance of religion and education on university students' views of evolution in the Deep South and state science standards across the United States. Evol Educ Outreach. 2014;7(1):1-7. https://doi.org/10.1186/ s12052-014-0024-1.

Romine WL, Walter EM, Bosse E, Todd AN. Understanding patterns of evolution acceptance-a new implementation of the Measure of Acceptance of the Theory of Evolution (MATE) with Midwestern university students. J Res Sci Teach. 2017;54(5):642-71. https://doi.org/10.1002/ tea.21380.

Rughiniş C. A lucky answer to a fair question: conceptual, methodological, and moral implications of including items on human evolution in scientific literacy surveys. Sci Commun. 2011;33(4):501-32. https://doi.org/10. 1177/1075547011408927.

Rutledge ML, Warden MA. Evolutionary theory, the nature of science \& high school biology teachers: critical relationships. Am Biol Teach. 2000;62:23-31. https://doi.org/10.1662/0002-7685(2000)062[0023: ETTNOS]2.0.CO;2.

Sammet K. Religion, Geschlechterordnungen und Generativität. [Religion, gender orders and generativity]. In: Sammet K, Benthaus-Apel F, Gärtner C, editors. Religion und Geschlechterordnungen. Veröffentlichungen der Sektion Religionssoziologie der Deutschen Gesellschaft für Soziologie. Wiesbaden: Springer; 2017. p. 49-78.

Sá-Pinto X, Pinto A, Ribeiro J, Sarmento I, Pessoa P, Rodrigues LR, Vázquez-Ben L, Mavrikaki E, Bernardino LJ. Following Darwin's footsteps: evaluating the impact of an activity designed for elementary school students to link historically important evolution key concepts on their understanding of natural selection. Ecol Evol. 2021a;11(18):12236-50.

Sá-Pinto X, Realdon G, Torkar G, Sousa B, Georgiou M, Jeffries A, et al. Development and validation of a framework for the assessment of school curricula on the presence of evolutionary concepts (FACE). Evol Educ Outreach. 2021b;14(1):3.

Sbeglia GC, Nehm RH. Measuring evolution acceptance using the GAENE: Influences of gender, race, degree-plan, and instruction. Evol Educ Outreach. 2018;11(1):1-9. https://doi.org/10.1186/s12052-018-0091-9.

Sbeglia GC, Nehm RH. Illuminating the complexities of conflict with evolution: validation of the scales of evolutionary conflict measure (SECM). Evol Educ Outreach. 2020;13(1):1-22.

Scott EC. Evolution vs. creationism: an introduction: an introduction. Westport: Greenwood Publishing Group; 2008.

Sinatra GM, Southerland SA, McConaughy F, Demastes JW. Intentions and beliefs in students' understanding and acceptance of biological evolution. J Res Sci Teach. 2003;40(5):510-28. https://doi.org/10.1002/tea. 10087.

Smith MU, Siegel H. On the relationship between belief and acceptance of evolution as goals of evolution education. Sci Educ. 2016;25(5):473-96. https://doi.org/10.1007/s11191-016-9836-4.

Smith MU, Snyder SW, Devereaux RS. The GAENE-generalized acceptance of evolution evaluation: development of a new measure of evolution acceptance. J Res Sci Teach. 2016;53(9):1289-315. https://doi.org/10. 1002/tea.21328.

Snijders TA. Fixed and random effects. In: Everitt BS, Howell DC, editors. Encyclopedia of statistics in behavioral science. Chicester: Wiley; 2005. p. 664-5. https://doi.org/10.1002/0470013192.bsa234. 
Šorgo A, Usak M, Kubiatko M, Fanèovièova J, Prokop P, Puhek M, Skoda J, Bahar M. A cross-cultural study on freshmen's knowledge of genetics, evolution, and the nature of science. J Balt Sci Educ. 2014;13(1):6-18.

Southcott R, Downie JR. Evolution and religion: attitudes of Scottish bioscience students to the teaching of evolutionary biology. Evol Educ Outreach. 2012;5(2):301-11. https://doi.org/10.1007/s12052-012-0419-9.

Southerland SA, Scharmann LC. Acknowledging the religious beliefs students bring into the science classroom: using the bounded nature of science. Theory Pract. 2013;52(1):59-65. https://doi.org/10.1080/07351690.2013. 743778.

Stanisavljevic J, Papadopoulou P, Djuric D. Relationship between acceptance and understanding of the evolution theory by various groups of teachers. Croat J Educ. 2013;15(3):693-714.

Tekkaya C, Akyol G, Sungur S. Relationships among teachers' knowledge and beliefs regarding the teaching of evolution: a case for Turkey. Evol Educ Outreach. 2012;5(3):477-93. https://doi.org/10.1007/ s12052-012-0433-y.

Tolman ER, Ferguson DG, Hubble G, Kaloi M, Niu M, Jensen JL. Barriers to teaching evolution in higher education. Evol Educ Outreach. 2021;14(1):1-6.

Torkar G, Šorgo A. Evolutionary content knowledge, religiosity and educational background of slovene preschool and primary school pre-service teachers. Eurasia J Math Sci Teach. 2020;16(7):em1855. https://doi.org/ $10.2307 / 4451708$

Trani R. I won't teach evolution; It's against my religion. And now for the rest of the story... The American Biology Teacher; 2004. pp 419-27.

Yasri P, Mancy R. Student positions on the relationship between evolution and creation: what kinds of changes occur and for what reasons? J Res Sci Teach. 2016;53(3):384-99. https://doi.org/10.1002/tea.21302.

Yüce Z, Önel A. Fen Öğretmen Adaylarının Bilimin Doğasını Anlamaları Ve Evrim Teorisini Kabul Düzeylerinin Belirlenm. [The comprehension of nature of science by science teacher candidates and the determination of their acceptance levels of evolutionary theory]. Electron Turk Stud. 2015;10:857-72. https://doi.org/10.7827/TurkishStudies.8476.

\section{Publisher's Note}

Springer Nature remains neutral with regard to jurisdictional claims in published maps and institutional affiliations.

Ready to submit your research? Choose BMC and benefit from:

- fast, convenient online submission

- thorough peer review by experienced researchers in your field

- rapid publication on acceptance

- support for research data, including large and complex data types

- gold Open Access which fosters wider collaboration and increased citations

- maximum visibility for your research: over $100 \mathrm{M}$ website views per year

At BMC, research is always in progress.

Learn more biomedcentral.com/submissions 